\title{
Geochemistry of the Serra das Melancias Pluton in the Serra da Aldeia Suite: a classic post-collisional high Ba-Sr granite in The Riacho do Pontal Fold Belt, NE Brazil
}

Geoquímica do Plúton Serra das Melancias, Suíte Serra da Aldeia: um clássico granito pós-colisional de alto Ba-Sr na Faixa Riacho do Pontal, NE Brasil

\author{
Marcela Paschoal Perpétuo ${ }^{1}$, Wagner da Silva Amaral ${ }^{1 *}$, Felipe Grandjean da Costa ${ }^{2}$, \\ Evilarde Carvalho Uchôa Filho ${ }^{3}$, Daniel Francisco Martins de Sousa ${ }^{1}$
}

\begin{abstract}
The Serra da Aldeia Suite is composed by circular or oval-shaped plutons, intrusive in meta-sedimentary and meta-volcanosedimentary rocks in the Riacho do Pontal Fold Belt, NE Brazil. The Serra das Melancias Pluton, belonging to Serra da Aldeia Suite, is located southeastern of Piaui state, near Paulistana city. These plutons represent a major magmatic expression in this area and contain important information about the late magmatic/collisional geologic evolution of the Brasiliano Orogeny. Based on petrographic and geochemical data, three facies were defined in the Serra das Melancias Pluton: granites, syenites and quartz monzonites. The rocks display high- $\mathrm{K}$ and alkaline to shoshonitic affinities, are metaluminous and show ferrous character. They are enriched in Light Rare Earth Elements and Large Ion Lithophile Elements, with negative anomalies in $\mathrm{Nb}, \mathrm{Ta}$ and $\mathrm{Ti}$. Their high $\mathrm{Ba}, \mathrm{Sr}, \mathrm{K} / \mathrm{Rb}$, low $\mathrm{Rb}$, relatively low $\mathrm{U}$, $\mathrm{Th}, \mathrm{Nb}$ to very low Heavy Rare Earth Elements and $\mathrm{Y}$ resemble those of typical high Ba-Sr granitoids. The geochemical data suggest the emplacement of Serra das Melancias Pluton in a transitional, late to post-orogenic setting in the Riacho do Pontal Fold Belt during the late Brasiliano-Pan African Orogeny.
\end{abstract}

KEYWORDS: alkaline granites; geochemistry; Riacho do Pontal Fold Belt; Borborema Province; high Ba-Sr granites.

\begin{abstract}
RESUMO: A suite Serra da Aldeia é composta por plútons graniticos circulares ou ovalados, intrusivos em sequências metassedimentares e metavulcanossedimentares na Faixa Riacho do Pontal, Nordeste do Brasil. O Plúton Serra das Melancias, pertencente à suite Serra da Aldeia, está localizado no sudeste do Piauí, próximo ao município de Paulistana. Esse plúton representa a principal expressão magmática nessa região e contém importantes informaçôes sobre a evolução geológica e o magmatismo tardicolisional durante a Orogenia Brasiliana. Com base em dados de campo, petrográficos e geoquimicos, foram definidas três fácies para o Plúton Serra das Melancias: granitos, sienitos e quartzo monzonitos. As rochas apresentam afinidades alcalinas de alto $K$ a shoshoniticas, metaluminosas, e mostram caráter ferroso. São enriquecidas em elementos litófilos de grande raio iônico e elementos terras raras leves, com anomalias negativas de $\mathrm{Nb}$, Ta e Ti. Os valores muito elevados de $B a$, Sr e K/Rb, baixo $R b, U$, Th, Nb e muito baixos de elementos terras raras pesados são típicos de granitoides de alto Ba-Sr. Assim, os dados geoquímicos sugerem a colocação do Plúton Serra da Aldeia em um ambiente transicional entre tardi a pós-colisional na Faixa Riacho do Pontal, nos estágios finais da Orogenia Brasiliano-Pan Africana.
\end{abstract}

PALAVRAS-CHAVE: granitos alcalinos; geoquimica; Faixa Riacho do Pontal; Provincia Borborema; granitos alto Ba-Sr.

${ }^{1}$ Instituto de Geociências, Universidade Estadual de Campinas - UNICAMP, Campinas (SP), Brazil. E-mail: marcela.perpetuo@gmail.com,wamaral@ige.unicamp.br, danfms@gmail.com

${ }^{2}$ Companhia de Pesquisa de Recursos Minerais - CPRM, Fortaleza (CE), Brazil. E-mail: felipe.costa@cprm.gov.br

${ }^{3}$ CPRM, Teresina (PI), Brazil. E-mail: evilarde.uchoa@cprm.gov.br

*Corresponding author.

Manuscript ID: 20160002. Received in: 01/06/2016. Approved in: 04/28/2016. 


\section{INTRODUCTION}

The collision between continental masses during the formation of supercontinents triggers the closing of oceans in subduction zones and the generation of magmatic arcs with intense production of granitic magmatism (Trompette 1994). The Riacho do Pontal Fold Belt (Brito Neves 1975), localized in the southern domain of the Borborema Province, between the São Francisco Craton and the PernambucoOeste Shear Zone (Fig. 1A), was involved in the western Gondwana amalgamation process during the Brasiliano-Pan African Orogeny (Almeida et al. 1981, Caxito et al. 2014). The Riacho do Pontal Fold Belt is composed of an ample suite of magmatic rocks marked by intense deformation and metamorphism. Among these rocks, a basement formed by tonalite-trondhjemite-granodiorite (TTG) migmatites and granitoids, amphibolite-facies metasedimentary and meta-volcanosedimentary sequences stands out, not to mention syn-, late- and post-collisional magmatic intrusions of granitic to syenitic composition (Brito Neves 1975, Caxito 2013).

According to Oliveira (1998), the Riacho do Pontal Fold Belt is divided from south to north in three domains (external, central and internal) with distinct lithological and tectono-metamorphic characteristics. The northwestern region of the orogen, which is restricted to the internal domain, is characterized by intense late-to post-orogenic magmatism (Brito Neves et al. 2015). The intrusive bodies that belong to this magmatism are situated in the southern margin of the Parnaíba Basin and were named Serra da Aldeia Suite by Gava et al. (1984). These plutons are oval to circular, trend approximately NE-SW, and are considered as the last magmatic event of the Riacho do Pontal Fold Belt (Caxito 2013, Brito Neves et al. 2015).

Gava et al. (1984) and Plá Cid et al. (2000) presented petrologic, petrographic and geochemical data for a group of rocks from the Serra da Aldeia Suite plutons. These are $\mathrm{Sr}$ - and Ba-enriched and Rb-depleted rocks, which prevents $\mathrm{Rb}-\mathrm{Sr}$ age determination for this expressive suite. More recent geochemical data presented by Melo and Guimarães (2011) include rocks that belong to the southwestern portion of the Serra da Aldeia Suite. Despite the attention given to these intrusive bodies by the aforementioned studies, little work has been done on these intrusions in the internal domain of the Riacho do Pontal Fold Belt.

The aim of this research is the detailed petrographic and geochemical study of the largest pluton of the Serra da Aldeia Suite, represented by the circular-shaped Serra das Melancias pluton (Fig. 1B). Besides the petrographic and geochemical data, a geologic map (1:50000) of the pluton is presented, with emphasis on the distinct magmatic facies that constitute the body. Finally, a discussion of its petrogenesis and relationship with post-collisional magmatism in the Riacho do Pontal Fold Belt is presented in the context of the evolution of the western Gondwana supercontinent.

\section{REGIONAL GEOLOGIC CONTEXT}

The Riacho do Pontal Fold Belt is divided in three domains or zones, according to distinct metamorphic and structural characteristics. Such features were recognized thanks to geophysical studies developed by Oliveira (1998), which allowed the division of the orogen, from south to north, in external zone, central zone and internal zone.

The external domain is characterized by a system of nappes extending southward towards the São Francisco Craton, represented by the Casa Nova Group (Souza et al. 1979, Santos \& Silva Filho 1990, Figuerôa \& Silva Filho 1990, Bizzi et al. 2007, Caxito 2013). The Casa Nova Group is composed of clastic metasedimentary rocks of Neoproterozoic age (Brito Neves et al. 2015) and is constituted by two main units: the Barra Bonita Formation, mainly composed of metapelitic rocks, such as schists and phyllites, and muscovite quartzites, besides calcitic marble intercalations, which is characterized as shallow marine platform deposits (Caxito 2013); and the Mandacaru Formation, where micaschists intercalated with metagraywacke predominate, associated with a flysch-type, deep turbiditic marine environment (Caxito 2013). The basement of this zone is composed of partially migmatized TTG-type orthogneisses represented by the Sobradinho Block (Angelim \& Kosin 2001, Dantas et al. 2010), and is characterized by thin-skinned tectonics. The Sobradinho Block, as well as the other portions that represent the basement of the São Francisco Craton to the north, is considered by Brito Neves et al. (2015) as a $200 \mathrm{~km}$ wide foreland thrust and fold belt.

The central domain is recognized as an E-W trending synformal structure named Monte Orebe Synform (Kreysing et al. 1973, Angelim 1988, Moraes 1992), represented by the Monte Orebe Complex. This complex is constituted by a metavolcano sedimentary sequence composed mainly of basic metavolcanics (actinolite greenschists, amphibolites, metatuffs), with intercalations of ultramafic and metasedimentary rocks, such as metachert, garnet mica schists, graywacke and quartz schists (Caxito 2013). Based on geophysical studies, Oliveira (1998) suggests the existence of a suture zone in the region, as evidenced by Bouger anomalies with positive-negative pairs. A recent study by Caxito et al. (2014) showed a mid-ocean ridge basalt (MORB) type affinity for the basic metavolcanics, with a whole-rock $\mathrm{Sm}-\mathrm{Nd}$ isochron at around $819 \pm 120 \mathrm{Ma}$. The authors suggest that the Monte Orebe Complex contains remnants of Neoproterozoic oceanic 
crust and corroborate a possible suture zone in the region. The Neoproterozoic age for this complex is still questionable. More precise and refined geochronologic studies are necessary to constrain the age of these rocks.
The internal domain is predominantly composed of meta-volcanosedimentary sequences represented by the Paulistana and Santa Filomena complexes (Gomes \& Vasconcelos 1991, Angelim \& Kosin 2001) and the Morro

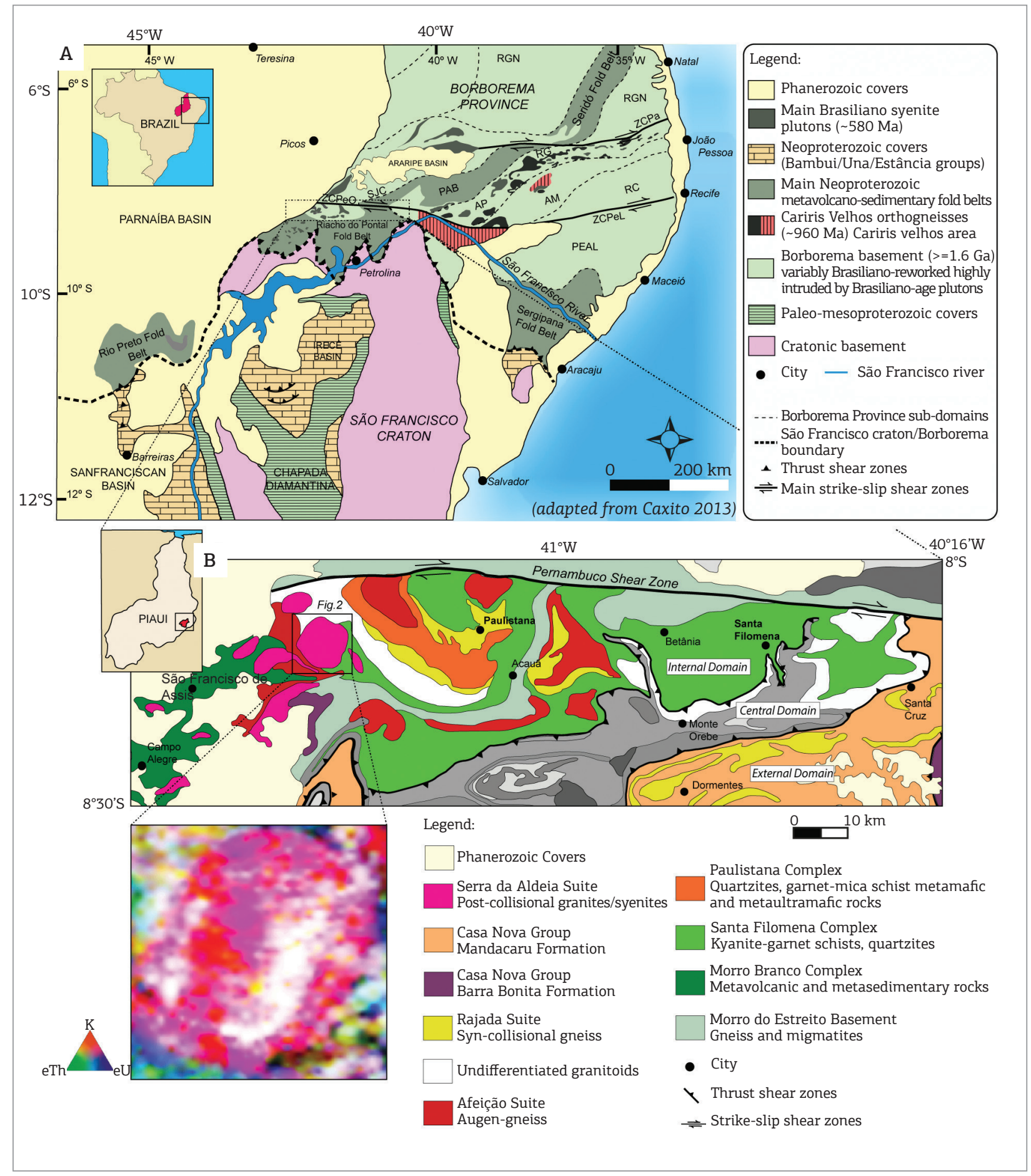

Figure 1. Geotectonic setting of: (A) southern part of Borborema Province (RGN: Rio Grande do Norte; RC: Rio Capibaribe; PEAL: Pernambuco/Alagoas; AM: Alto Moxotó; AP: Alto Pajeú; ZCPa: Zona de Cisalhamento Patos; ZCPeO: Zona de Cisalhamento Pernambuco Oeste; ZCPeL: Zona de Cisalhamento Pernambuco Leste, modified after Caxito 2013); (B) internal domain of Riacho do Pontal Orogen, showing in detail the Serra das Melancias Pluton in a gammaespectrometric image. 
Branco Complex (Caxito 2013) (Fig. 1B). The Santa Filomena Complex is mainly constituted by muscovite-biotite schists with garnet and locally kyanite, calcitic marbles that grade to calc-schists, quartz schists, and quartzitic lenses at the base of mafic-ultramafic bodies (Caxito 2013). An assemblage of quartzite-pelite-carbonate (QPC) type is also identified in this sequence. The Santa Filomena Complex is considered to be of Neoproterozoic age, based on $800-750 \mathrm{Ma} \mathrm{U-Pb}-$ LA-ICP-MS ages of detrital zircons in schists (Brito Neves et al. 2015). The Paulistana Complex is a plutono-volcano sedimentary unit composed predominantly of garnet-mica schists, muscovite-quartz schists, metachert, greenschists (metabasalts) and amphibolites (metagabbros), besides ultramafic schists. A Tonian age is inferred from zircon $\mathrm{U}-\mathrm{Pb}$ by ca. 888 Ma LA-ICP-MS ages of a metagabbro intrusive in the Paulistana Complex (Caxito 2013, Brito Neves et al. 2015). The Morro Branco Complex, located to the west of the internal domain, is mainly composed of metarhythmites with basic to acid metavolcanic and metatuff intercalations. It is considered to be $1.0 \mathrm{Ga}$ or older, based on minimum ages obtained for a granitic sill in the complex (Caxito 2013). The Morro Branco Complex is intruded by mafic-ultramafic bodies of the Brejo Seco (Marimon 1990, Salgado 2014) and São Francisco de Assis (Caxito 2013) complexes. Besides, porphyritic granites and augen gneisses representative of the Afeição Suite are abundant in the internal domain. The Afeição Suite yields Tonian ages varying between 942 and $988 \mathrm{Ma}$, obtained from whole rock Rb-Sr isochrons and zircon U-Pb (Jardim de Sá et al. 1988, Rb-Sr isochrons; Van Schmus et al. 1995, U-Pb TIMS; Caxito et al. 2014, LA-ICP-MS; Brito Neves et al. 2015, LA-ICP-MS), thus being related to the Cariris Velhos event.

The basement of the central and internal domains is represented by tonalitic to granodioritic orthogneisses with migmatized portions, named Morro do Estreito Complex (Kosin et al. 2004), and is characterized by a thick-skinned tectonic style. Gava et al. (1983) presented a whole rock $\mathrm{Rb}-\mathrm{Sr}$ age of $1.9 \mathrm{Ga}$ for the rocks of this basement. In turn, Brito Neves et al. (2015) attributed a ca. 2.6 Ga Neoarchean age (whole rock Rb-Sr isochrons and U-Pb LA-ICP-MS in zircon) for the granodioritic orthogneisses of this basement, considered by the authors as the hinterland portion of the folded belt.

The regional metamorphism of Riacho do Pontal Fold Belt is dated at $636 \pm 15 \mathrm{Ma}$, based on zircon U-Pb (LA-ICP-MS) ages from the Rajada Suite (Rajada gneiss, Brito Neves et al. 2015). The metamorphism is high greenschist to amphibolite facies, configured in three progressive phases by the same compressive tectonic regime that generated the orogen structures. A transcurrent regime related to escape tectonics is represented by the western Pernambuco Shear Zone, with a metamorphic grade between amphibolite and granulite facies (Caxito 2013).

Finally, the Riacho do Pontal Fold Belt is intruded by different generations of syn-, late- to post-collisional igneous bodies related to the Brasiliano Orogeny. Syn-collisional magmatism is represented by the Rajada Suite, which is mainly composed of two-mica orthogneisses of tonalitic to granodioritic composition (Angelim 1988). Whole-rock $\mathrm{Rb}-\mathrm{Sr}$ isochrons yielded ages between $743 \pm 59$ and $539 \pm$ $25 \mathrm{Ma}$ for the Rajada Suite intrusion and metamorphism respectively (Jardim de Sá et al. 1988, Santos \& Silva Filho 1990). Zircon U-Pb (LA-ICP-MS) between 570 and $616 \mathrm{Ma}$ are presented by Caxito (2013). In turn, Brito Neves et al. (2015) obtained ages between 620 and $636 \mathrm{Ma}$ by zircon $\mathrm{U}-\mathrm{Pb}$ (LA-ICP-MS), representative of the metamorphic peak. Syn- to late-orogenic magmatism is represented by the Serra da Esperança Suite, which is composed of gray to pink syenites and quartz syenites (Plá Cid et al. 2000). A whole rock Rb-Sr age of $555 \pm 10 \mathrm{Ma}$ was obtained for one pluton from this suite (Jardim de Sá et al. 1996). The late- to post-orogenic magmatism is represented by the Serra da Aldeia Suite.

One of the plutons related to this magmatism, located in the Riacho do Pontal Fold Belt Internal Zone, corresponds to the study area. The Serra da Aldeia Suite is characterized by NE-SW-trending oval and circular bodies, composed of gray to pink syenites and alkaline granites. The plutons occurrence concentrated in the northwestern region of the orogen internal domain (Caxito 2013, Caxito \& Uhlein 2013). Geochemically, the Serra da Aldeia Suite represents high $\mathrm{K}$ calc-alkaline to shoshonitic intrusions (Gava et al. 1984, Plá Cid et al. 2000).

\section{METHODS}

Fifteen samples (Fig. 2) were analyzed in the Institute of Geoscience of the State University of Campinas (UNICAMP) laboratories for whole-rock geochemistry. Major and some trace elements were analyzed in the X-Ray Fluorescence Laboratory, using pressed pellets to obtain the trace elements and glass discs for major elements. The equipment used was a Philips PW2404 X-Ray fluorescence spectrometer. To control the quality of the results, a disc of the international reference material BRP-1, with three samples of international reference materials (GSP-2, BE-N and BRP-1), was prepared and analyzed. Trace elements, including REEs, were analyzed in the Isotopic Geology Laboratory by ICP-MS X series II (Thermo) equipped with a Collision Cell Technology (CCT). The samples were dissolved with nitric and hydrofluoric acids in Parr bombs for five days. The mass spectrometer was calibrated 


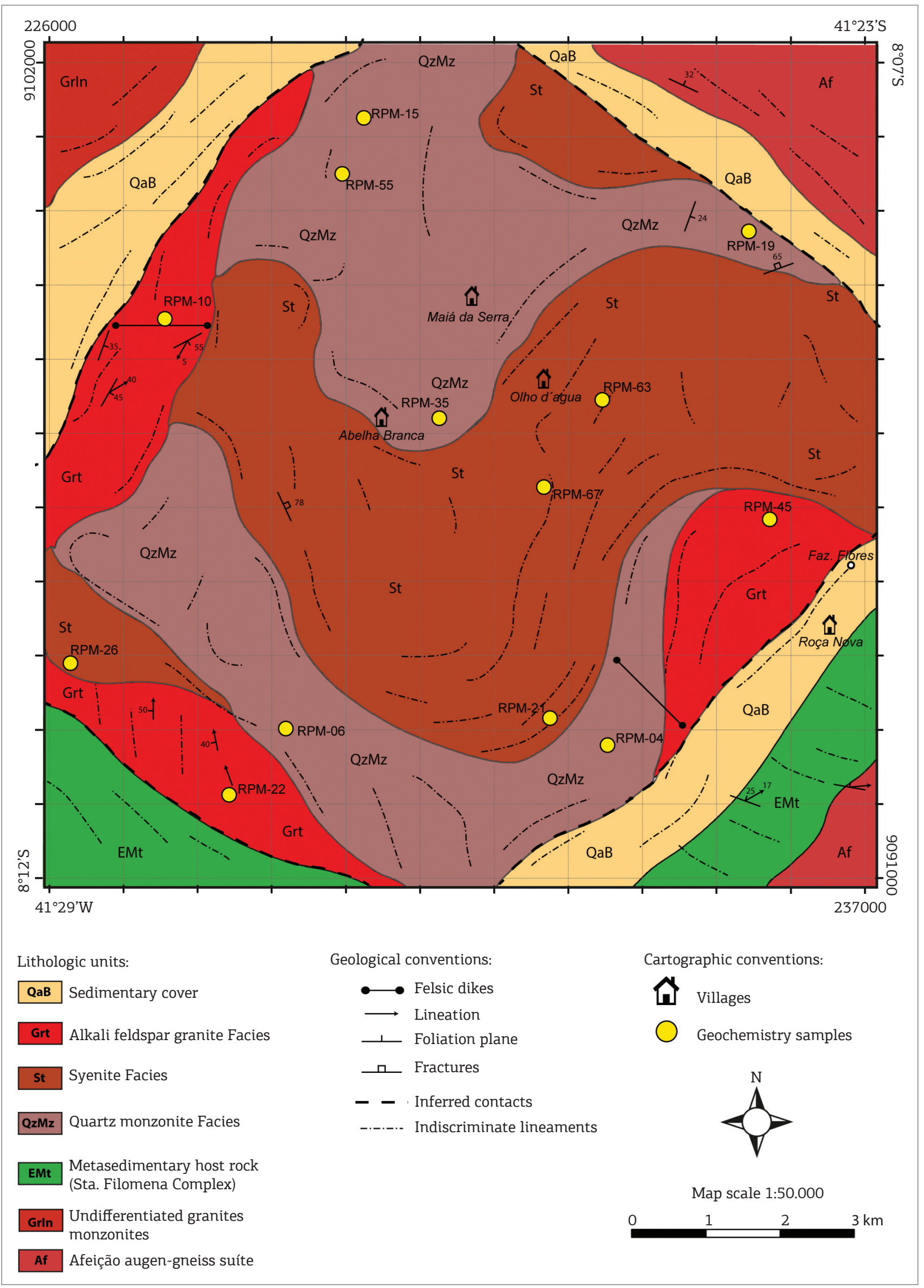

Figure 2. Geological map (1:50.000) of the Serra das Melancias Pluton. 
using multi-element solutions, which were prepared gravimetrically using mono-element standard solutions $(100 \mathrm{mg} / \mathrm{L}$, AccuStandards). For quality control, the reference material GS-N (Granite - ANRT, France) was used.

\section{RESULTS}

\section{Geological features and petrography}

The Serra das Melancias Pluton (Fig. 3A) is a circular pluton of approximately $84 \mathrm{~km}^{2}$ in area. The outcrops include blocks, slabs and boulders, which may be weathered. The pluton is intrusive into metasedimentary sequences of biotite schists belonging to the Santa Filomena Complex. Most parts of the pluton are isotropic with some evidence of strain close to the borders. The borders are mylonitized, with the presence of massive milky quartz blocks, indicating local shear and suggesting late emplacement for this body. Three faciologic facies were discriminated: granites, quartz monzonites and syenites.

The syenites constitute the most central portion of the pluton and occur in blocks and slabs which can be fractured and faulted (b). The syenites exhibit pink to reddish gray color, equigranular to slightly inequigranular texture of medium-grained $(4 \mathrm{~mm})$ alkaline feldspar and amphibole crystals. The syenites occurring at the edges of the pluton are slightly anisotropic, marked by the orientation of mafic minerals. Under the microscope, the syenites present glomeroporphyritic texture, with clusters of alkaline feldspar and amphibole crystals. The main mineral phases are microcline (50 to $65 \%$ vol.), albite $(-15-45 \%$ modal) confirmed by X-ray diffractometry (XRD), and quartz (7\%). The main mafic mineral is arfvedsonite ( $-7 \%$ vol.) (Fig. $3 \mathrm{C})$. Its occurrence was also confirmed by X-ray diffractometry. Hornblende ( $-2 \%$ modal), epidote $(3 \%)$, biotite $(4 \%)$ and diopside $(-3 \%)$ occur in smaller amounts, with typical accessory phases, such as carbonate, titanite, apatite, zircon and opaque minerals (ca. $2 \%$ vol.). Microcline with perthitic texture and zoned plagioclase are also observed.

Quartz monzonites occur in the northernmost and southernmost parts of the pluton (Fig. 2) as large blocks, which are sometimes fractured. They are crosscut by NW-SE-trending pegmatitic and E-W-trending aplitic dikes, which can exhibit cooling rims. A single mafic enclave was found in this unit, in a block of quartz monzonitic composition, characterized by a discrete orientation of mafic minerals. The quartz monzonites present pink to grayish color, equigranular to slightly inequigranular texture of medium-grained $(6 \mathrm{~mm})$ amphibole crystals. With the exception of foliated varieties along the borders of the pluton, the quartz monzonites are isotropic (Fig. 3D). Under the microscope, the matrix shows a medium grained equigranular hypidiomorphic texture. The main mineral phases are microcline and orthoclase (together making up $-35 \%$ vol.), albite $(-40 \%)$, confirmed by XRD, quartz $(-13 \%)$, and arfvedsonite as the main mafic mineral $(-5 \%)$. Accessory mineral phases are epidote $(-3 \%)$, biotite $(-1 \%)$, diopside $(-1 \%)$, allanite, titanite, clinozoisite, apatite, zircon and opaque minerals (ca. $2 \%$ vol.). In addition, an altered aegirine-augite crystal surrounded by arfvedsonite was identified, suggesting substitution (Fig. 3E). Quartz crystals can show mosaic texture, and epidote crystals occur associated with arfvedsonite, surrounding opaque minerals or shows allanite nuclei. Thus, allanite exhibits a texture typical of magmatic (primary) epidote ("type A" epidote, Sial et al. 2008, Brasilino et al. 2011).

The granites occur close to the borders of the pluton, in contact with quartz blocks and the metasedimentary host (Fig. 2). They are deformed, with oriented mafic minerals. E-W trending aplitic dikes of quartz monzonitic composition occur at some outcrops. Close to the border of the pluton an intrusive contact relationship between an intensively sheared granitoid injection from the Afeição Suite and a finer-grained, isotropic granitic intrusion, considered part of the Serra das Melancias Pluton granitic unit, was observed. The granites are medium-grained phaneritic, pink to dark gray and show equigranular hypidiomorphic texture (Fig. 3F). The main mineral phases are microcline $(-17 \%$ modal $)$, plagioclase $(-10 \%)$, albite $(-35 \%)$, quartz $(-24 \%)$, and arfvedsonite $(-5 \%)$ as main mafic mineral. Accessory mineral phases include epidote $(-3 \%)$, diopside $(-1 \%)$, hornblende $(\sim 1 \%)$, and biotite $(\sim 1 \%)$, together with allanite, titanite, apatite, zircon and opaque minerals (totalizing -3\% vol.) (Fig. 3G). Quartz crystals exhibit mosaic texture, whereas albite crystals can show myrmekitic texture and zoning. Epidote presents "type A" magmatic texture, with allanite nuclei.

\section{Geochemistry}

The chemical data obtained for the representative samples of Serra das Melancias Pluton are presented in Table 1 (XRF and ICP-MS).

The rocks show alkaline affinity, as observed in the Totalalkali-silica (TAS) diagram (Middlemost 1985), where we can see that all rocks plot in the alkaline rocks field, above the Irvine and Baragar (1971) curve (Fig. 4A). Considering the $\mathrm{SiO}_{2}$ content of the analyzed samples, the syenites yield concentrations from 63.07 to $66.23 \%$, the quartz monzonites from 66.69 to $69.41 \%$, and the granites between 71.3 and $72.46 \%$. In turn, the aplitic dike yields $67.9 \%$ $\mathrm{SiO}_{2}$. The high $\mathrm{K}$ content and shoshonitic affinity are also characteristic, as shown in the $\mathrm{K}_{2} \mathrm{O}$ versus $\mathrm{SiO}_{2}$ diagram 
A
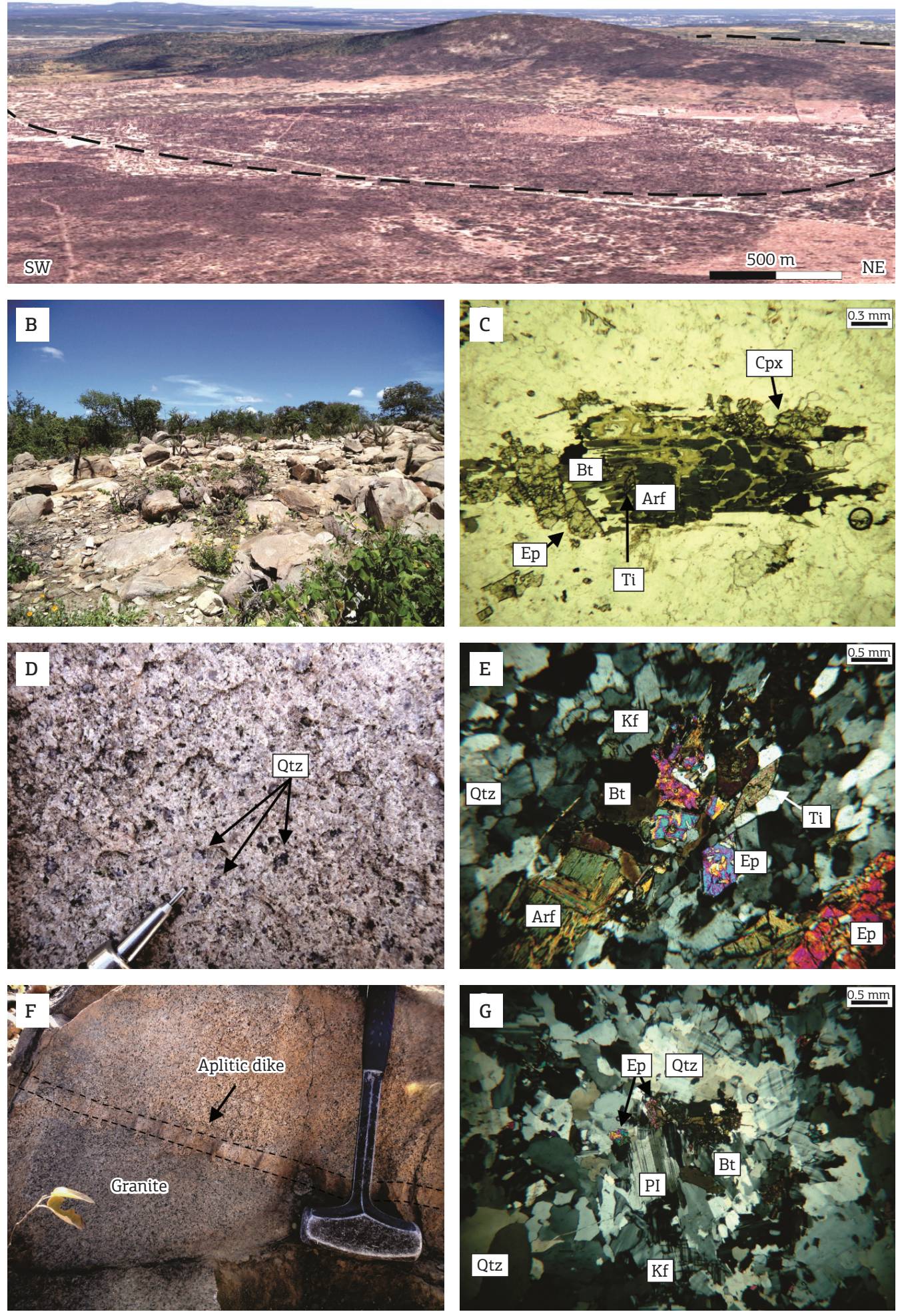

Figure 3. Main features of the rocks of the Serra das Melancias Pluton. (A) photo of the Serra das Melancias Pluton; (B) syenite blocks of the pluton (RPM-67); (C) photomicrography showing agglomerate crystal with clinopyroxene (Cpx), arfvedsonite (Arf), biotite (Bt), titanite (Ti) and epidote (Ep) within an alkali-feldspar (Kf) groundmass of the syenites (RPM-63); (D) quartz-monzonite highlighting quartz crystals (RPM-54); (E) photomicrography showing altered arfvedsonite (Arf), epidote (Ep), diopside (Di), clinozoisite and titanite (Ti) (RPM-4B); (F) granite (RPM-31); (G) photomicrography showing quartz crystals with polygonal boundaries (RPM-10A). 
Table 1. Geochemical data obtained by XRF and ICP-MS for the Serra das Melancias Pluton.

\begin{tabular}{|c|c|c|c|c|c|c|c|c|c|c|c|c|c|c|c|}
\hline Sar & $\begin{array}{c}\text { RPM- } \\
26\end{array}$ & $\begin{array}{c}\text { RPM- } \\
63\end{array}$ & $\begin{array}{c}\text { RPM- } \\
67\end{array}$ & $\begin{array}{c}\text { RPM- } \\
21\end{array}$ & $\begin{array}{c}\text { RPM- } \\
\text { 4A }\end{array}$ & $\begin{array}{c}\text { RPM- } \\
55\end{array}$ & $\begin{array}{l}\text { RPM- } \\
\text { 10B }\end{array}$ & $\begin{array}{c}\text { RPM- } \\
15\end{array}$ & $\begin{array}{c}\text { RPM- } \\
\text { 4B }\end{array}$ & $\begin{array}{c}\text { RPM- } \\
35\end{array}$ & $\begin{array}{c}\text { RPM- } \\
06\end{array}$ & $\begin{array}{c}\text { RPM- } \\
19\end{array}$ & $\begin{array}{l}\text { RPM- } \\
\text { 10A }\end{array}$ & $\begin{array}{c}\text { RPM- } \\
45\end{array}$ & $\begin{array}{c}\text { RPM- } \\
22\end{array}$ \\
\hline (\%) & 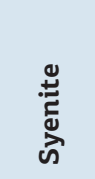 & $\begin{array}{l}\text { के } \\
\text { के } \\
\text { के }\end{array}$ & के & के & 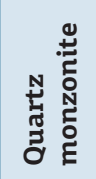 & 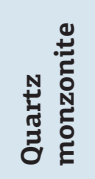 & 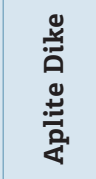 & 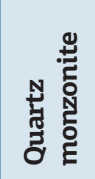 & 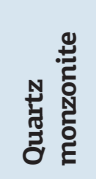 & 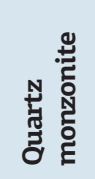 & 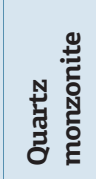 & 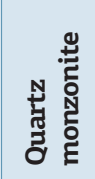 & 芯 & 芯 & 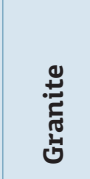 \\
\hline $\mathrm{SiO}_{2}$ & 3.07 & 63.95 & 5.92 & 66.23 & 6.69 & 67.38 & 7.90 & 67.94 & 68.31 & 68.4 & 68.66 & 69.41 & 1.30 & 2.08 & 72.46 \\
\hline $\mathrm{TiO}_{2}$ & 0.35 & 0.22 & 0.20 & 0.20 & 0.17 & 0.17 & 0.22 & 0.20 & 0.16 & 0.31 & 0.15 & 0.17 & 0.11 & 0.10 & 0.06 \\
\hline $\mathrm{Al}_{2} \mathrm{O}_{3}$ & 18.24 & 18.52 & 17.84 & 17.73 & 17.78 & 16.93 & 16.04 & 16.38 & 17.20 & 17.29 & 16.81 & 16.30 & 15.29 & 15.80 & 15.51 \\
\hline $\mathrm{Fe}_{2} \mathrm{O}_{3}$ & 3.16 & 2.17 & 1.97 & 2.18 & 1.74 & 1.91 & 2.04 & 2.20 & 1.53 & 1.38 & 1.53 & 1.39 & 1.50 & 0.85 & 0.67 \\
\hline $\mathrm{MnO}$ & 0.11 & 0.08 & 0.07 & 0.1 & 0.06 & 0.06 & 0.07 & 0.07 & 0.05 & 0.05 & 0.06 & 0.03 & 0.06 & 0.03 & 0.01 \\
\hline $\mathrm{MgO}$ & 0.59 & 0.40 & 0.34 & 0.36 & 0.30 & 0.35 & 0.52 & 0.51 & 0.24 & 0.30 & 0.24 & 0.25 & 0.19 & 0.14 & 0.06 \\
\hline $\mathrm{CaO}$ & 3.19 & 1.69 & 1.61 & 2.06 & 1.90 & 1.97 & 2.04 & 1.93 & 1.37 & 1.43 & 1.57 & 1.36 & 1.40 & 1.29 & 0.69 \\
\hline $\mathrm{Na}_{2} \mathrm{O}$ & 5.30 & 6.72 & 6.51 & 5.99 & 5.77 & 5.84 & 5.38 & 5.36 & 5.87 & 5.92 & 5.84 & 5.85 & 5.02 & 5.32 & 5.49 \\
\hline $\mathrm{K}_{2} \mathrm{O}$ & 5.07 & 5.14 & 4.84 & 4.62 & 4.89 & 4.44 & 4.64 & 4.88 & 4.86 & 4.17 & 4.43 & 4.24 & 4.42 & 3.94 & 4.70 \\
\hline $\mathrm{P}_{2} \mathrm{O}_{5}$ & 0.12 & 0.08 & 0.07 & 0.09 & 0.07 & 0.07 & 0.10 & 0.11 & 0.04 & 0.09 & 0.06 & 0.07 & 0.05 & 0.03 & 0.02 \\
\hline LOI & 0.86 & 0.22 & 0.16 & 0.21 & 0.31 & 0.16 & 0.24 & 0.34 & 0.25 & 0.26 & 0.32 & 0.27 & 0.24 & 0.26 & 0.26 \\
\hline Total & 100.1 & 99.2 & 99.5 & 99.8 & 99.7 & 99.3 & 99.2 & 99.3 & 99.9 & 99.6 & 99.7 & 99.2 & 99.6 & 99.8 & 99.9 \\
\hline \multicolumn{16}{|l|}{ (ppm) } \\
\hline $\mathrm{Ba}$ & 4013 & 3756 & 2951 & 3430 & 3098 & 2532 & 1196 & 2712 & 3234 & 3865 & 2577 & 3171 & 1782 & 2310 & 3095 \\
\hline $\mathrm{Sr}$ & 1590 & 2212 & 1084 & 1627 & 1042 & 797 & 312 & 1117 & 1349 & 1542 & 896 & 920 & 449 & 809 & 1003 \\
\hline $\mathrm{Zr}$ & 2 & 3 & 243 & 0 & 2 & 188 & 10 & n & 36 & 197 & 182 & 75 & 0 & 110 & 78 \\
\hline $\mathrm{Rb}$ & 62.2 & 74.8 & 40.2 & 75.1 & 80.7 & 49.9 & 113.1 & 92.4 & 65.0 & 50 & 81.6 & 62.2 & 72.2 & 75.7 & 56.5 \\
\hline Cs & 2 & 9 & 11 & 4 & 1.32 & 5 & 83 & 7 & 57 & 94 & 65 & 43 & 25 & 1 & 0.84 \\
\hline $\mathrm{Li}$ & 11.2 & 8.59 & 8.27 & 13.8 & 14.0 & 11.1 & 4.40 & 13.8 & 6.93 & 8.66 & 10.6 & 12.0 & 11.4 & 3.60 & 5.57 \\
\hline $\mathrm{Pb}$ & 39.5 & 54.5 & 43.8 & 44.2 & 42.3 & 33.4 & 1.3 & 50.7 & 32.6 & 43.0 & 39.4 & 4.9 & 22.7 & 35.7 & 48.5 \\
\hline $\mathrm{Nb}$ & 18.3 & 21.9 & 16.9 & 210 & 143 & 7 & 147 & 5.8 & 20.8 & 16.7 & .4 & 16.2 & 10.4 & 9.35 & 15.3 \\
\hline $\mathrm{Y}$ & 14.9 & 18.9 & 7.97 & 14.5 & 6.84 & 7.31 & 4.59 & 10.6 & 7.04 & 6.73 & 8.60 & 4.98 & 9.58 & 2.59 & 9.07 \\
\hline $\mathrm{Ga}$ & 181 & 19.8 & 50 & 1 & 2 & 1 & 11.7 & 17.9 & 7.5 & 2 & 6 & 7 & 8 & 7 & .2 \\
\hline Sc & 3.99 & 2.72 & $<\mathrm{LD}$ & 2.53 & 1.91 & $<\mathrm{LD}$ & $<\mathrm{LD}$ & 3.62 & 1.66 & $<\mathrm{LD}$ & $<\mathrm{LD}$ & $<\mathrm{LD}$ & $<\mathrm{LD}$ & $<\mathrm{LD}$ & 2.37 \\
\hline Th & 8.21 & 14.6 & 6.44 & 1 & 3.07 & 9 & 48 & כ & 39 & 12 & 21 & 1 & 21 & 1 & 6.19 \\
\hline $\mathrm{U}$ & 1.30 & .72 & 1.72 & 2.33 & 1.08 & 1.00 & 2.38 & 1.41 & 1.18 & 0.82 & 0.61 & 0.55 & 0.43 & 0.96 & 1.10 \\
\hline $\mathrm{V}$ & 33.7 & 21.5 & 18.1 & 25.1 & 21.4 & 15.6 & 6.90 & 21.1 & 16.5 & 13.4 & 16.1 & 11.2 & 15.8 & 10.9 & 25.2 \\
\hline בר & 30.0 & 50.6 & 20.7 & 27.7 & 7.96 & 10.3 & 437 & 175 & 13.5 & 22.3 & 13.6 & 16.5 & 8.59 & 2.73 & 16.8 \\
\hline $\mathrm{Ce}$ & 61.8 & 80.0 & 29.1 & 52.3 & 13.5 & 24.5 & 7.46 & 34.7 & 19.0 & 29.3 & 16.2 & 24.7 & 8.21 & 4.13 & 29.2 \\
\hline $\mathrm{P}$ & 6.56 & 12 & 5.08 & 34 & 7 & 50 & 1.00 & 3.90 & 2.78 & 5.26 & 97 & 3.77 & 1.99 & 0.60 & 30 \\
\hline $\mathrm{Nd}$ & 25.9 & 38.9 & 19.6 & 25.3 & 7.05 & 10.1 & 4.01 & 15.0 & 10.0 & 20.1 & 11.7 & 13.8 & 7.86 & 2.52 & 14.4 \\
\hline $\mathrm{Sm}$ & 5.30 & 7.07 & 3.44 & 5 & 1.47 & 2.27 & 0.94 & 3.00 & 92 & 3.09 & 2.37 & 2.41 & 1.67 & .58 & 2.82 \\
\hline $\mathrm{Eu}$ & 1.83 & 2.23 & 1.20 & 1.70 & 0.67 & 0.83 & 0.35 & 1.05 & 0.81 & 1.36 & 0.85 & 0.89 & 0.60 & 0.35 & 1.03 \\
\hline $\mathrm{Gd}$ & 4.54 & 5.76 & 2.63 & 4.30 & 1.42 & 1.93 & 0.92 & 2.65 & 1.58 & 2.52 & 2.04 & 1.69 & 1.59 & 0.49 & 2.37 \\
\hline $\mathrm{Tb}$ & 0.56 & 0.69 & 0.33 & 0.57 & 0.20 & 0.27 & 0.14 & 0.36 & 0.23 & 0.28 & 0.28 & 0.19 & 0.24 & 0.07 & 0.32 \\
\hline Dy & 3.01 & 3.58 & 1.69 & 2.95 & 1.20 & 1.38 & 0.82 & 2.01 & 1.32 & 1.30 & 1.57 & 0.95 & 1.49 & 0.41 & 1.72 \\
\hline Ho & 0.52 & 0.64 & 0.30 & 0.51 & 0.24 & 0.25 & 0.16 & 0.37 & 0.25 & 0.22 & 0.30 & 0.17 & 0.30 & 0.09 & 0.31 \\
\hline
\end{tabular}


Table 1. Continuation.

\begin{tabular}{|c|c|c|c|c|c|c|c|c|c|c|c|c|c|c|c|}
\hline & $\begin{array}{c}\text { RPM- } \\
26\end{array}$ & $\begin{array}{c}\text { RPM- } \\
63\end{array}$ & $\begin{array}{c}\text { RPM- } \\
67\end{array}$ & $\begin{array}{c}\text { RPM- } \\
21\end{array}$ & $\begin{array}{c}\text { RPM- } \\
\text { 4A }\end{array}$ & $\begin{array}{c}\text { RPM- } \\
55\end{array}$ & $\begin{array}{c}\text { RPM- } \\
\text { 10B }\end{array}$ & $\begin{array}{c}\text { RPM- } \\
15\end{array}$ & $\begin{array}{c}\text { RPM- } \\
\text { 4B }\end{array}$ & $\begin{array}{c}\text { RPM- } \\
35\end{array}$ & $\begin{array}{c}\text { RPM- } \\
06\end{array}$ & $\begin{array}{c}\text { RPM- } \\
19\end{array}$ & $\begin{array}{c}\text { RPM- } \\
10 A\end{array}$ & $\begin{array}{c}\text { RPM- } \\
45\end{array}$ & $\begin{array}{c}\text { RPM- } \\
22\end{array}$ \\
\hline & $\begin{array}{l}\stackrel{ \pm}{ \pm} \\
\text { के }\end{array}$ & 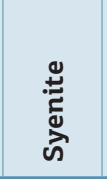 & $\begin{array}{l}\stackrel{ \pm}{ \pm} \\
\text { के }\end{array}$ & $\begin{array}{l}\text { ڤँ } \\
\text { के } \\
\text { के }\end{array}$ & 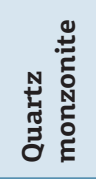 & 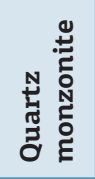 & 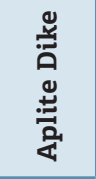 & 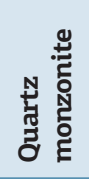 & 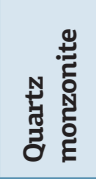 & 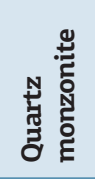 & 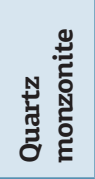 & 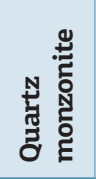 & 苋 & 苞 & 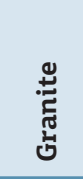 \\
\hline $\mathrm{EI}$ & & 85 & 20 & 1.10 & & 74 & & & & 63 & 87 & 0 & & & \\
\hline $\mathrm{T} c$ & 79 & 1.12 & 0.01 & 0.96 & 0.67 & 0.66 & 0.77 & 0.71 & 1.03 & 0.73 & 0.75 & 0.72 & 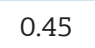 & .44 & .69 \\
\hline $\mathrm{Tn}$ & 1 & 0.25 & 0.13 & 0.21 & 0 & 0.10 & 0.07 & 16 & 0.11 & 08 & .12 & .07 & 3 & .05 & 0.13 \\
\hline $\mathrm{Yb}$ & \pm 4 & 67 & (3) & 40 & 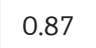 & 77 & 44 & 20 & 79 & 56 & .83 & .46 & 0.88 & 3 & 1.00 \\
\hline $\mathrm{Lu}$ & 19 & 0.23 & 12 & 0.21 & 0.12 & 0.11 & 0.06 & 18 & 0.11 & 0.07 & 0.12 & 0.07 & 0.12 & 0.05 & 0.15 \\
\hline Hf & 76 & 7.89 & 12 & 61 & 4.96 & 38 & 25 & 51 & .91 & 5.36 & 5.08 & 5.23 & כ & .33 & .02 \\
\hline$(\mathrm{La} / \mathrm{Yb})_{\mathrm{N}}$ & 28 & 45 & 10 & 38 & 6.18 & 00 & 72.2 & 81 & 6. & 6.89 & 1.15 & 4.11 & 6.59 & 5.53 & 11.34 \\
\hline$(\mathrm{La} / \mathrm{Sm})_{\mathrm{N}}$ & 56 & 51 & 3.78 & - & 3.41 & 85 & 2.92 & 60 & 4.42 & 3.80 & 3.61 & 4.31 & 4 & 2.96 & 3.74 \\
\hline$(\mathrm{Ce} / \mathrm{Yb})_{\mathrm{N}}$ & 1128 & 12.40 & 8.70 & 9.68 & 4.00 & 8.21 & 4.41 & 7.45 & 6.26 & 0 & 28 & 4 & 2.42 & 3.21 & 57 \\
\hline$(\mathrm{Ce} / \mathrm{Sm})_{\mathrm{N}}$ & 2.81 & 2.73 & 2.04 & 2.44 & 2.21 & 2.60 & 1.91 & 2.74 & 2.39 & 1.92 & 1.65 & 2.47 & 1.19 & 1.72 & 2.50 \\
\hline$(\mathrm{Eu} / \mathrm{Yb})_{\mathrm{N}}$ & 3.67 & 3.79 & 3.92 & 3.46 & 2.21 & 3.05 & 2.24 & 2.49 & 2.95 & 6.91 & 3 & 5.51 & 1.94 & 2.96 & 5 \\
\hline $\mathrm{Eu} / \mathrm{Eu}^{*}$ & 1.14 & & & & & & & & 43 & 1.36 & .18 & 1.36 & 3 & 2.00 & 1.22 \\
\hline$\Sigma_{\mathrm{REE}}$ & 143.44 & 203.64 & 86.13 & 30.19 & 37.26 & 56.01 & 21.19 & 3.22 & 53.18 & 87.57 & 53.84 & 66.10 & 34.54 & 2.68 & 4.95 \\
\hline
\end{tabular}

(Peccerillo \& Taylor 1976) (Fig. 4B). The alkaline affinity of the rocks can also be seen in the $\mathrm{Na}_{2} \mathrm{O}+\mathrm{K}_{2} \mathrm{O}-\mathrm{CaO}$ versus $\mathrm{SiO}_{2}$ diagram (Modified Alkaline Index, Frost et al. 2001) (Fig. 4C). The characteristics obtained for this index reflect the composition of the K-feldspars present in the rocks. The samples are also ferrous according to the chemical classification proposed by Frost et al. (2001), using the FeOt/ $(\mathrm{FeOt}+\mathrm{MgO})$ versus $\mathrm{SiO}_{2}$ diagram (Fig. 5A). The dominantly ferrous character observed in these rocks suggests reduced magmas, which underwent low oxygen fugacity. The ferrous trend can indicate that the rocks underwent iron enrichment before the alkalis enrichment by means of magmatic differentiation, such as hornblende and biotite crystallization (Frost \& Frost 2014). The high Fe content can also reflect basaltic sources of reduced character (Frost et al. 2001).

The rocks are metaluminous, plotting very close to the limit with the peraluminous field, as can be seen in the A/NK versus A/CNK diagram (Maniar \& Piccoli 1989), often known as Shand Index (Fig. 5B). The observed metaluminous character $(\mathrm{A} / \mathrm{CNK}<1)$ reflects the presence of calcic minerals, such as diopside and hornblende ( $-3 \%$ modal). The samples plot close to the limit between the Metaluminous/ Peralkaline domains, yielding A/NK between 1.0 and 1.4. This reflects the presence of Na-rich amphiboles, such as arfvedsonite, confirmed by XRD analysis.

The analyzed rocks show a negative correlation between $\mathrm{Al}_{2} \mathrm{O}_{3}, \mathrm{MgO}, \mathrm{CaO}, \mathrm{FeOt}, \mathrm{TiO}_{2}, \mathrm{P}_{2} \mathrm{O}_{5}$ and $\mathrm{MnO}$ and $\mathrm{SiO}_{2}$, as observed in Harker's chemical variation diagrams for major elements (Fig 6). Regarding $\mathrm{Na}_{2} \mathrm{O}$ and $\mathrm{K}_{2} \mathrm{O}$ variations, despite the scattering of these oxide contents, a negative correlation with $\mathrm{SiO}_{2}$ is observed, which may reflect high $\mathrm{Na}$ and $\mathrm{K}$ contents associated with the abundance of alkaline feldspars in these rocks. In general, the rocks are characterized by low $\mathrm{MgO}$ contents (between 0.05 and $0.6 \%$ ), when compared to FeOt (between 0.5 and 3.0\%) as confirmed in the Frost's diagram. Low $\mathrm{CaO}$ contents (between 0.5 and $2.5 \%$ ), when compared to alkalis $\left(\mathrm{Na}_{2} \mathrm{O}\right.$ between 5.0 and $7.0 \%$, and $\mathrm{K}_{2} \mathrm{O}$ between 3.8 and 5.2\%) reflect the abundance of alkaline feldspars, when compared to calcic plagioclase.

Regarding trace elements, in general, the rocks, especially the syenites, yield high Ba (up to $-4000 \mathrm{ppm}$ ) and Sr (up to $-2200 \mathrm{ppm}$ ) contents, with the lowest values observed in the aplitic dike ( $-300 \mathrm{ppm} \mathrm{Sr}$ and $1200 \mathrm{ppm}$ $\mathrm{Ba})$. Low Rb contents lower than 120 ppm are also observed. The Sr-Rb-Ba triangular diagram (Fig. 7) shows a trend towards $\mathrm{Ba}$, known as the $\mathrm{HiBaSr}$ trend, typical of high Ba-Sr granitoids (Tarney \& Jones 1994).

The samples present a negative correlation of $\mathrm{Ba}, \mathrm{Sr}$, $\mathrm{Nb}, \mathrm{Ni}, \mathrm{Y}, \mathrm{Zr}$ and $\mathrm{Zn}$ with $\mathrm{SiO}_{2}$, (see Harker diagrams for selected trace elements, Fig. 8). The behavior observed in the variation diagrams, expressing the negative correlation between the selected elements and $\mathrm{SiO}_{2}$, indicates fractional crystallization process in the evolution of this magmatic suite. Nevertheless, the also observed scattered behavior suggests 


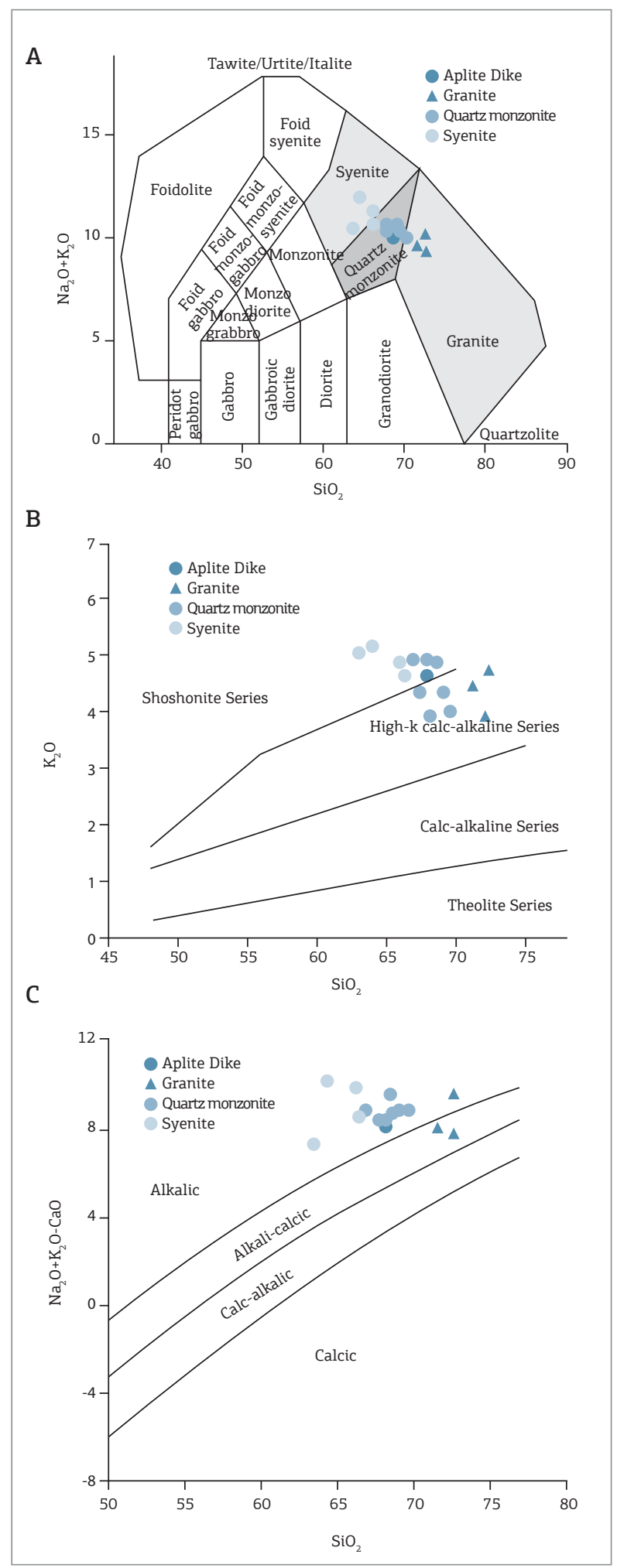

Figure 4. (A) $\mathrm{Na}_{2} \mathrm{O}+\mathrm{K}_{2} \mathrm{O}$ versus $\mathrm{SiO}_{2}$ diagram (Middlemost 1985) with the curve to distinguishing alkali from subalkalic magmatic series according to Irvine and Baragar (1971); (B) $\mathrm{K}_{2} \mathrm{O}$ versus $\mathrm{SiO}_{2}$ diagram (Peccerillo \& Taylor 1976); (C) $\mathrm{Na}_{2} \mathrm{O}+\mathrm{K}_{2} \mathrm{O}-\mathrm{CaO}$ versus $\mathrm{SiO}_{2}$ diagram after Frost et al. (2001), for samples from the Serra das Melancias Pluton. different geological processes, such as mixing or even distinct effects that should be investigated (Rollinson 1993).

Chondrite-normalized REE patterns (Boynton 1984) are presented in Fig. 9A. The rocks show a more evident Light Rare Earth Elements (LREE) enrichment relatively to the chondrite than Heavy Rare Earth Elements (HREE), which results in fractionation of these groups as attested by $(\mathrm{La} / \mathrm{Yb})_{\mathrm{N}}$ values. The granites show a low fractionation $\left((\mathrm{La} / \mathrm{Yb})_{\mathrm{N}}=5-11\right)$, similar to the syenites $\left((\mathrm{La} / \mathrm{Yb})_{\mathrm{N}}=13-20\right)$, whereas the quartz monzonites exhibit a moderate fractionation with $(\mathrm{La} / \mathrm{Yb})_{\mathrm{N}}=6-27$. The lithotypes show slightly positive Eu anomalies with $\mathrm{Eu} / \mathrm{Eu}^{*}$ values between 1.13-2.0 for granites, 1.06-1.21 for syenites, and 1.13-1.4 for the quartz monzonites with the highest positive $\mathrm{Eu}$ anomaly for the granite sample RPM-45. The observed positive Eu anomalies may be related to the presence of feldspars, and to a lesser extent hornblende, mineral phases that accommodate $\mathrm{Eu}^{2+}$ in their crystalline structures by $\mathrm{Ca}^{2+}$ replacement (Rollinson 1993, Winter 2001).

The primitive mantle-normalized multi-element diagram (spidergram) of Sun and McDonough (1989) (Fig. 9B) shows a more pronounced enrichment in Large Ion Lithophile Elements (LILE) than High Field Strength Elements (HFSE) relatively to the primitive mantle, with marked positive $\mathrm{Ba}$, $\mathrm{K}$ and $\mathrm{Sr}$ anomalies. In turn, $\mathrm{Nb}, \mathrm{P}$ and $\mathrm{Ti}$ show negative anomalies, which may be related to fractionation of these elements in mineral phases, such as ilmenite, rutile and titanite, which may have remained in the source. Positive $\mathrm{K}$ anomalies result from the abundant presence of alkaline feldspar, which can also explain the positive $\mathrm{Ba}$ anomalies, element that substitutes $\mathrm{K}$ in alkaline feldspars.

All rocks plot in the Late-orogenic field of the multicationic R1-R2 diagram (Batchelor \& Bowden 1985) (Fig.10), evidencing a post-collisional setting for the Serra das Melancias Pluton, which is part of the Serra da Aldeia Suite. This setting is also suggested by the tectonic discrimination $(\mathrm{Rb}$ versus $\mathrm{Y}+\mathrm{Nb}$ ) diagram proposed by Pearce (1996) (Fig.11), where the samples plot in the post-collisional field, in intersection with the Volcanic Arc Granites (VAG) field.

\section{DISCUSSION}

The Serra das Melancias Pluton, which is part of the Serra da Aldeia Suite, shows high K and low Rb contents, resulting in high $\mathrm{K} / \mathrm{Rb}$ ratios; relatively low $\mathrm{Th}$ and $\mathrm{U}$ contents; negative $\mathrm{Nb}$ anomaly, very low $\mathrm{Y}$ and HREE contents, and very high $\mathrm{Ba}$ and $\mathrm{Sr}$ contents. These features are characteristics of high $\mathrm{Ba}$ and $\mathrm{Sr}$ granitoids ( $\mathrm{HiBaSr}$ ), as defined by Tarney and Jones (1994) for granitoids from the west Scotland area. The petrogenesis of these granitoids is still not 
well understood, but some suggestions have been proposed, such as: subduction of an oceanic plateau; underplating by high $\mathrm{Ba}-\mathrm{Sr}$ mafic magmas; lower lithosphere enrichment by carbonatitic melts (Tarney \& Jones 1994); partial melting of lithospheric mantle previously metasomatized by fluids resulting from subduction (Fowler et al. 2001); partial melting of the subcontinental lithospheric mantle enriched by means of sediments coming from subduction, which is considered analogous to the Neoarchean sanukitoids (Fowler \& Rollinson 2012); and mantle-crust magma mixing (Zhang et al. 2015).

The Serra das Melancias Pluton exhibits high-K alkaline to shoshonitic affinities, similar to post-collisional or late-orogenic suites affected by subduction-precedent events, as defined by Bonin et al. (1998). These geochemical features are associated with fluids resulting from subduction, with later metasomatism of the lithospheric mantle. Signature related to subduction can also be attested by negative $\mathrm{Ti}$ and $\mathrm{Nb}$ anomalies (Pearce 1982). Additionally, the rocks of the study area present geochemical features similar to those of "alkaline-type post-orogenic suite with aluminous trend" (Bonin et al. 1998), such as amphibole and alkaline feldspar fractionation and the presence of biotite (highlighting the aluminous trend), besides HFSE depletion relatively to LILE. According to the authors, the source for such suites is a depleted and later enriched mantle, with crustal contribution by contamination and assimilation. Thus, the Serra das Melancias Pluton presents characteristics of both late and post-orogenic suites, suggesting a transitional character between the two geodynamic settings.

According to the chemical diagrams by Frost et al. (2001), the dominantly ferrous, alkaline and metaluminous character of the studied rocks is chemically similar to that of granitoids previously defined as "A-type". However, this classification is restricted to chemical parameters without considering their tectonic setting, and do therefore not relate to the typically A-type granitoids discussed by Eby (1990, 1992).

However, the studied rocks show enrichment in alkalis $\left(\mathrm{Na}_{2} \mathrm{O}+\mathrm{K}_{2} \mathrm{O}>9\right.$ wt \%), as well as in $\mathrm{FeOt} /(\mathrm{FeOt}+\mathrm{MgO})$, and the presence of $\mathrm{Na}$-amphibole. Such characteristics allow us to classify these rocks as A-type granitoids (Nardi \& Bitencourt 2007, 2009).

Plá Cid et al. (2000) geochemically characterized the Serra da Aldeia Suite, or Engraçadinha Suite in their studies, as resulting from the ultrapotassic alkaline magmatism associated with the late stages of the Brasiliano Cycle, with geochemical characteristics related to a mantle source modified by subduction during the Rhyacian/Orosirian Orogeny.

Melo and Guimarães (2011) presented a set of geochemical data for granitic rocks from Serra da Aldeia Suite, southwest of the study area. The characteristics show metaluminous rocks with high-K calc-alkaline affinities, Ba-Sr enrichment, negative anomalies of Ti, Nb, P and enrichment in LREE relatively to HREE. A post-collisional magmatic
A

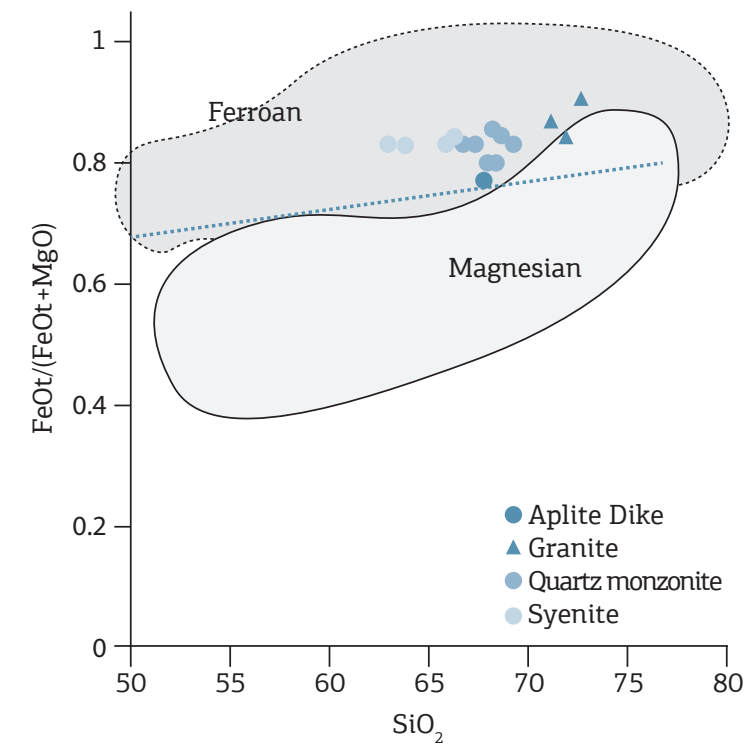

B

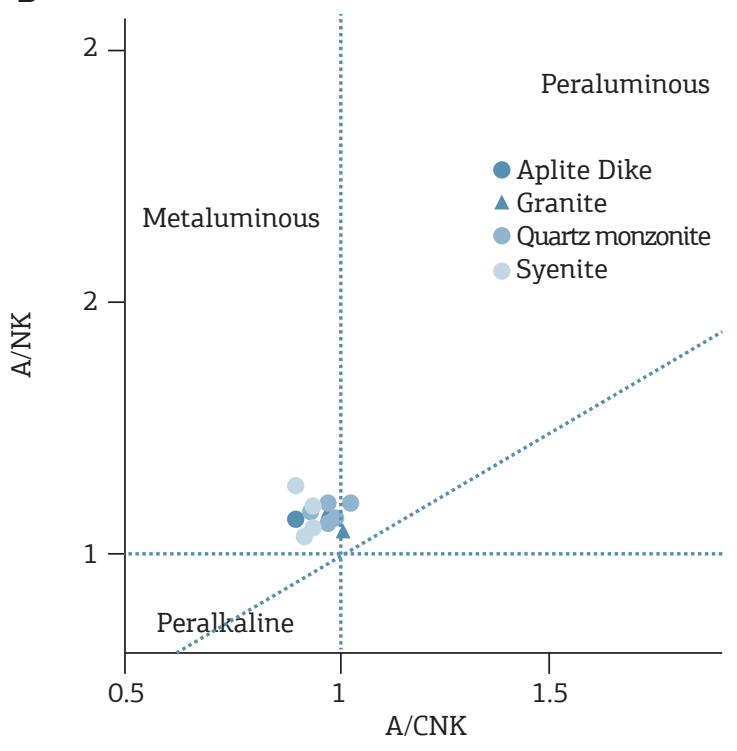

Figure 5. (A) $\mathrm{FeOt} /(\mathrm{FeOt}+\mathrm{MgO})$ versus $\mathrm{SiO}_{2}$ diagram (Frost et al. 2001) for Serra das Melancias Pluton samples; (B) $\mathrm{A} / \mathrm{NK}$ versus $\mathrm{A} / \mathrm{CNK}$ diagram after Maniar and Piccoli (1989): $\mathrm{A} / \mathrm{NK}: \mathrm{Al}_{2} \mathrm{O}_{3} /\left(\mathrm{Na}_{2} \mathrm{O}+\mathrm{K}_{2} \mathrm{O}\right)$ molar ratio; $\mathrm{A} / \mathrm{CNK} \mathrm{Al} \mathrm{O}_{3} /$ $\left(\mathrm{CaO}+\mathrm{Na}_{2} \mathrm{O}+\mathrm{K}_{2} \mathrm{O}\right)$ molar ratio. 
setting was proposed by the authors for this region. Thereby, the presented geochemistry features quite similar to those observed for the Serra das Melancias Pluton.

Recent studies based on isotopic and geochemical data presented by Caxito et al. (2014) attest to a MORB-type tholeiitic affiliation for the Monte Orebe Complex basic metavolcanic rocks, suggesting oceanic crust remnants in the region. This evidence is supported by gravimetric geophysical data presented by Oliveira (1998), attesting to a Bouger anomaly characterized by positive-negative pairs, which may indicate an old suture zone between two crustal blocks of distinct composition and density. Therefore, the remnants of oceanic crust would mark suture zones, suggesting a subduction setting, with the generation of the Serra da Aldeia Suite plutons related to the late stage, by means of the Brasiliano-Pan African collage.

Metaluminous, high-K to shoshonitic calc-alkaline rocks with very similar geochemical characteristics to those of the present study have been reported in several regions, for example, in southwestern Africa, Cameroon (BanefoMvoutsaha Massif, Nono et al. 2010), Nigeria (Aderan Area, Okonkwo \& Folorunso 2013), both of Neoproterozoic age,

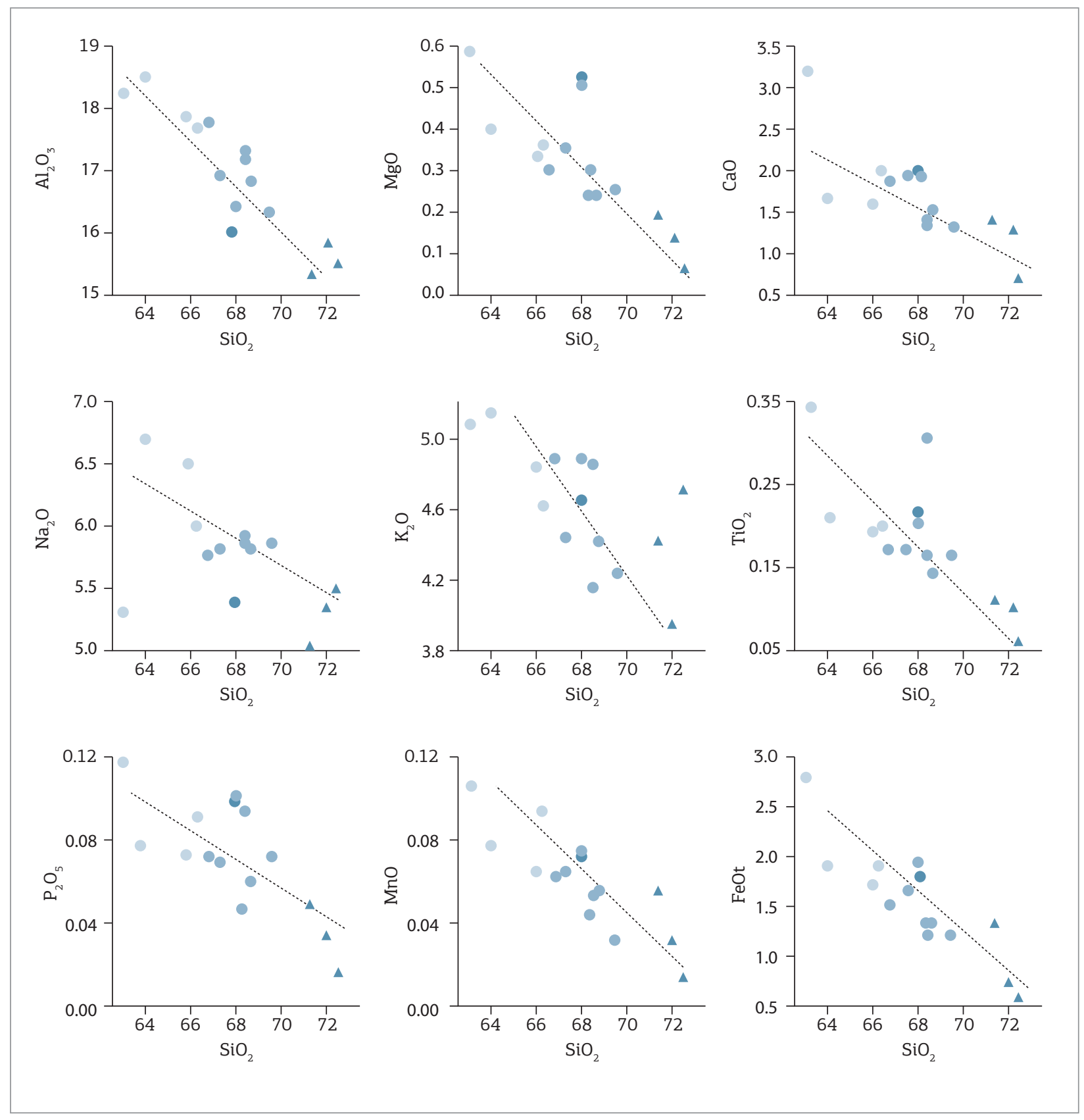

Figure 6. Harker variation diagrams for selected major elements expressed in oxides (weight \%) of rocks from Serra das Melancias Pluton. 


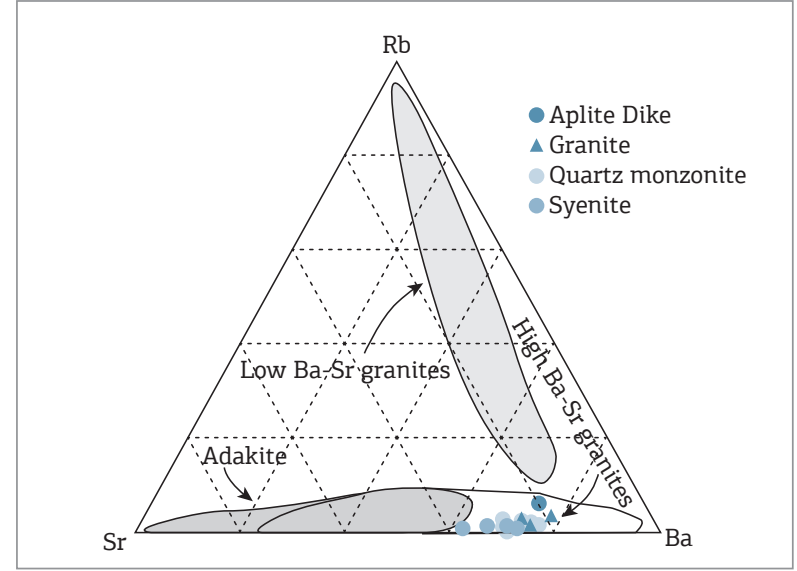

Figure 7. Sr-Rb-Ba ternary plot after Tarney and Jones (1994) illustrating the high Ba-Sr nature of rocks from Serra das Melancias Pluton. as well as eastern India (Mesoproterozoic PGG granitoids, Gonswami \& Bhattacharyya 2014). On the basis of their geochemical signatures presented, these rocks were related to late- to post-orogenic settings, with geochemical features associated with subduction zones.

Post-collisional alkaline magmatism related to the Neoproterozoic Brasiliano-Pan African orogeny has been also recognized in other parts of Brazil, particularly in the southern part of the country, such as alkaline granitic associations in the Saibro Suite (Nardi \& Bonin 1991); syenites and ultrapotassic granites of the Piquiri syenite Massif (Nardi et al. 2008) and monzonitic to granodioritic rocks belonging to the shoshonitic association of the Lavras do Sul (Liz et al. 2009). According to these authors, these rocks are derived from a mantle that was previously metasomatized by fluids from a subduction zone.

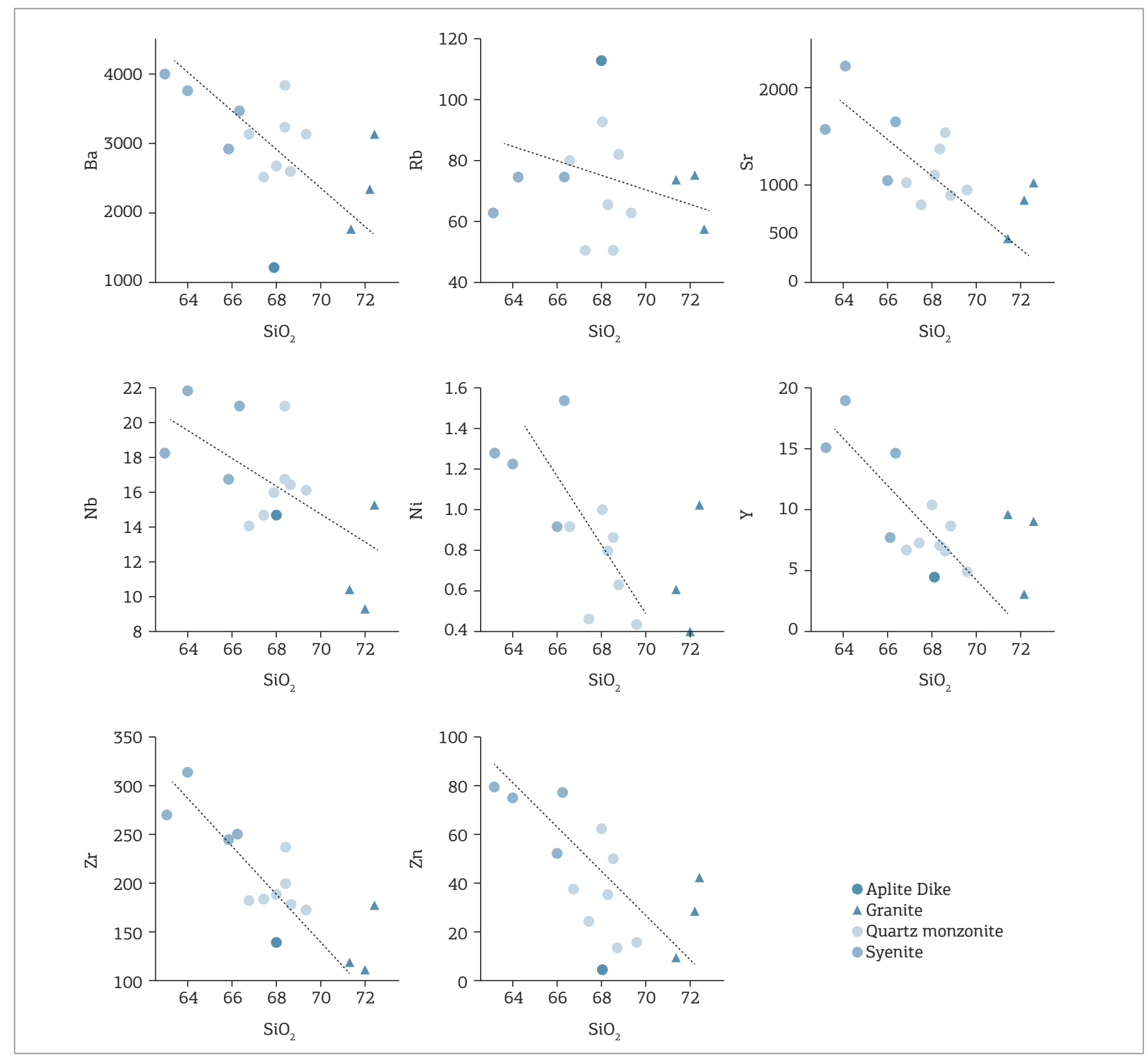

Figure 8. Harker variation diagrams for selected trace elements (ppm) versus $\mathrm{SiO}_{2}(\mathrm{wt} \%)$ contents for the Serra das Melancias Pluton. 


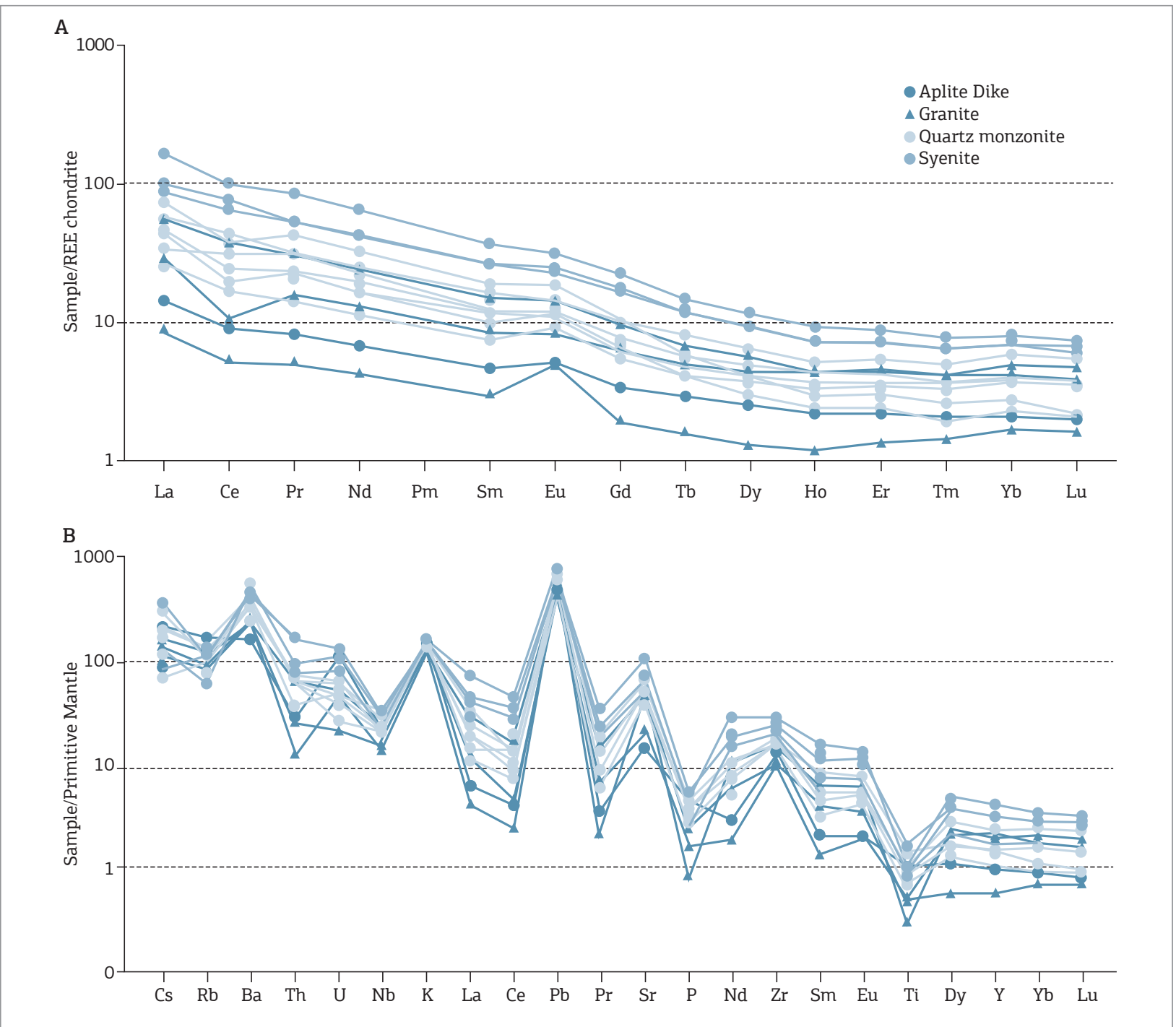

Figure 9. (A) Chondrite-normalized Rare Earth Element plots. Normalization values are from Boynton (1984); (B) mantle-normalized multi-element plots (Sun \& McDonough 1989) for the samples of Serra das Melancias.

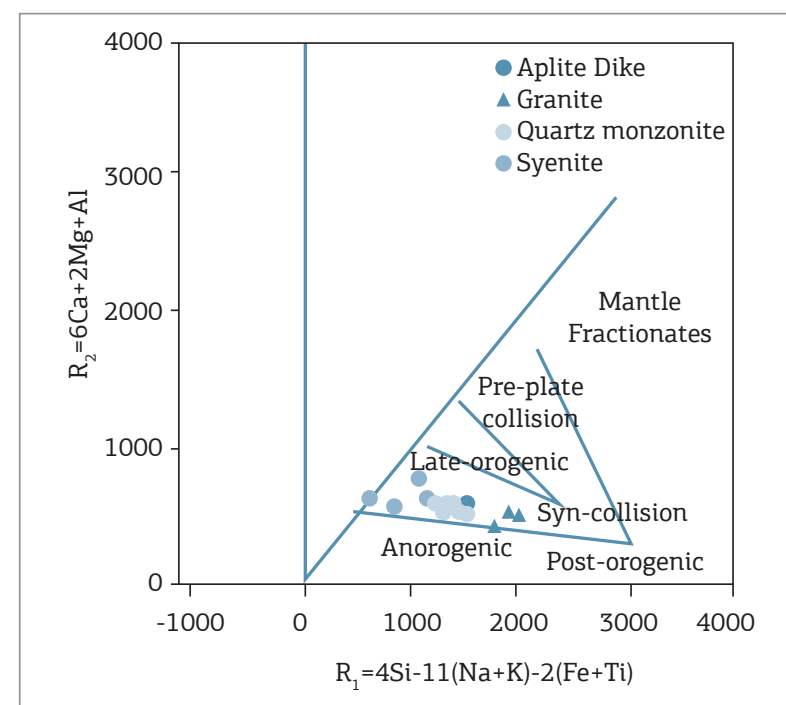

Figure 10. Multicationic diagram R1-R2 from Batchelor and Bowden (1985).

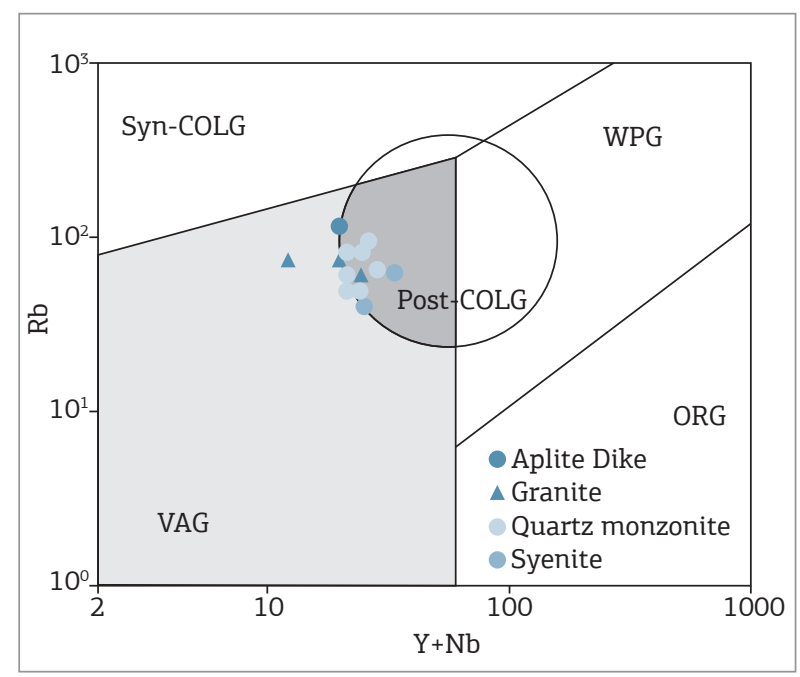

Figure 11. $\mathrm{Rb}$ versus $(\mathrm{Y}+\mathrm{Nb})$ diagram for discriminating the tectonic setting of granites (from Pearce et al. 1984) showing the post-COLG field after Pearce (1996). 
Some other Neoproterozoic examples in the southernmost Dom Feliciano Belt in Uruguay have also been reported, such as highly fractionated calc-alkaline granites, mildly alkaline granites, and shoshonitic and peralkaline intrusions formed in a post-collisional environment, transitional from orogenic to post-orogenic and associated with the evolution of shear zones (Oyhantçabal et al. 2007). More recently, in the same region of the Dom Feliciano Belt, geochemical data show the occurrence of high Ba-Sr granitic rocks with adakitic affinity (Lara et al. 2015).

Thus, from our data and interpretations, the rocks of the Serra das Melancias Pluton may be defined as high Ba-Sr granitoids, located in a late to post-orogenic context. The geochemical signatures attested by these rocks, such as the metaluminous character, high $\mathrm{K}$ to shoshonitic affinities, enrichment in LREE and LILE and Ti and $\mathrm{Nb}$ negative anomalies, may point to a derived mantle source, with the mantle being previously metasomatized by fluids coming from a subduction channel, with possible crustal contribution. However, the lack of geochemical data on mafic magmatic enclaves of the pluton makes it more difficult to characterize the mantle contribution during its petrogenesis. Additionally, isotopic geochemistry studies are necessary for a better understanding of the origin of the magmas, the processes involved, and also of the proposed tectonic setting.

\section{CONCLUSIONS}

Considering the field and petrographic data obtained for the Serra das Melancias Pluton, three main facies can be distinguished: quartz monzonitic, syenitic, and granitic. All the rock varieties are isotropic, except for the ones that occur along the margins of the pluton, where it is possible to observe sheared portions and contacts with quartz blocks. In general, the rocks are leucocratic, with well-preserved primary igneous textures. Exsolution textures and mineral intergrowth are common. The main mineral phases that characterize these rocks are alkaline feldspar, quartz and arfvedsonite, with subordinated aegirine-augite, hornblende and biotite, besides of accessory apatite, epidote, titanite, allanite and opaque minerals.

Whole-rock geochemical data reveal an alkaline affinity for the rocks of the pluton, which belongs to high $\mathrm{K}$ to shoshonitic series, besides ferrous and metaluminous character. Low $\mathrm{Rb}$ concentrations, high $\mathrm{K} / \mathrm{Rb}$ ratio, relatively low Th and $\mathrm{U}$ concentrations, negative $\mathrm{Nb}$ anomaly, very low Y and HREE concentrations, and high $\mathrm{Ba}$ and Sr values allow classification of the Serra das Melancias Pluton as high $\mathrm{Ba}-\mathrm{Sr}$ granitoids, similar to those proposed by Tarney \& Jones (1994) for granitoids from the west Scotland area.

The obtained set of data (field, petrographic and geochemical), with the tectonic discrimination diagrams, suggest a transitional, late- to post-orogenic setting for the suite. The presence of syenitic and quartz monzonitic facies with subduction geochemical signature probably reflects the magma source derivation from a subcontinental lithospheric mantle, previously metasomatized by early Neoproterozoic subduction event (enriched mantle). In this context, the emplacement of the Serra das Melancias Pluton is possibly associated with extensional collapse processes, postdating peak crustal thickening.

\section{ACKNOWLEDGMENTS}

The authors are grateful to Fundação de Amparo à Pesquisa do Estado de São Paulo (FAPESP), grants (2014/03275-3), for field work and laboratory support, and Conselho Nacional de Desenvolvimento Científico e Tecnológico (CNPq) for the research fellowship to WSA (Bolsa de Produtividade em Pesquisa). They also thank to Ricardo Borba and Dailto Silva, for their assistance with DRX data, and to Luana Florisbal, Ruy Philipp, Haakon Fossen (associate editor), for their constructive comments, which greatly improved the manuscript.

\section{REFERENCES}

Almeida F.F.M., Hasui Y., Brito Neves B.B., Fuck R.A. 1981. Brazilian structural provinces: an introduction. Earth Science Reviews, 17:1-29.

Angelim L.A.A. 1988. Programa Levantamentos Geológicos Básicos do Brasil-PLGB. Carta geológica, carta metalogenética, escala 1:1.000.000, folha SC.24-V-A-III. Santa Filomena, estados de Pernambuco e Piauí: DNPM/CPRM, 146 p.

Angelim L.A.A. \& Kosin M. (Orgs.) 2001. Programa Levantamentos Geológicos do Brasil, Folha Aracaju-NW. Nota explicativa. Brasília: CPRM - Serviço Geológico do Brasil, CD-ROM.
Batchelor R.A. \& Bowden P. 1985. Petrogenetic interpretation of granitoid rock series using multicationic parameters. Chemical Geology, 48:43-55.

Bizzi L.A., Schobbenhaus C., Gonçalves J.H., Baars F.J., Delgado I.M., Abram M.D., Neto R.L., Matos G.M.M., Santos J.O.S. 2007. Mapa geológico do Brasil, escala 1:2.500.000. Brasília: MME-CPRM, CD-ROM.

Bonin B., Azzouni-Sekkal A., Bussy F., Ferrag S. 1998. Alkali-calcic and alkaline post-orogenic (PO) granite magmatism: petrologic constraints and geodynamic settings. Lithos, 45(1):45-70. 
Boynton W.V. 1984. Cosmochemistry of the rare earth elements; meteorite studies. In: Henderson P. (Ed.). Rare Earth element geochemistry. Amsterdam: Elsevier. p. 63-114.

Brasilino R.G., Sial A.N., Ferreira V.P., Pimentel M.M. 2011. Bulck rock and mineral chemistries and ascent rates of high-K calc-alkali epidote-bearing magmas, Northeastern Brazil. Lithos, 127:441-454.

Brito Neves B.B. 1975. Regionalização geotectônica do Pré-Cambriano nordestino. PhD Thesis, Instituto de Geociências, Universidade de São Paulo, São Paulo, 198 p.

Brito Neves B.B., Van Schmus W.R., Angelim L.A.A. 2015. Contribuição ao conhecimento da evolução geológica do sistema Riacho do Pontal - PE, BA, PI. Revista do Instituto de Geociências - USP, 15:57-93.

Caxito F., Uhlein A., Stevenson R., Uhlein G.J. 2014. Neoproterozoic oceanic crust remnants in northeast Brazil. Geology, 42(5):387-390.

Caxito F.A. 2013. Geotectônica e evolução crustal das faixas Rio Preto e Riacho do Pontal, estados da Bahia, Pernambuco e Piauí. $\mathrm{PhD}$ Thesis, Instituto de Geociências, Universidade Federal de Minas Gerais, Belo Horizonte, 288 p.

Caxito F.A. \& Uhlein A. 2013. Arcabouço tectônico e estratigráfico da Faixa Riacho do Pontal, Divisa Pernambuco-Piauí-Bahia. Geonomos, 21(2):19-37.

Dantas E.L., Brito Neves B.B., Fuck R.A. 2010. Looking for the oldest rocks of South America: Paleoarchean orthogneiss of the Sobradinho Block, northernmost foreland of the Sao Francisco Craton, Petrolina, Pernambuco, Brasil. In: South American Symposium on Isotope Geology, 7, Brasília. Anais..., p. 137-140. CD-ROM.

Eby G.N. 1990. The A-type granitoids: a review of their occurrence and chemical characteristics and speculations on their petrogenesis. Lithos, 26(1):115-134.

Eby G.N. 1992. Chemical subdivision of the A-type granitoids: petrogenetic and tectonic implications. Geology, 20(7):641-644.

Figuerôa I. \& Siva Filho M.A. 1990. Programa Levantamentos Geológicos Básicos do Brasil. Carta Geológica, carta metalogenética, Escala 1:100.000, Folha SC.24-V-C-III. Petrolina, estados de Pernambuco e Bahia: DNPM/CPRM, 108 p.

Fowler M. \& Rollinson H. 2012. Phanerozoic sanukitoids from Caledonian Scotland: implications for Archean subduction. Geology, 40(12):1079-1082.

Fowler M.B., Henney P.J., Darbyshire D.P.F., Greenwood P.B. 2001. Petrogenesis of high Ba-Sr granites: the Rogart pluton, Sutherland. Journal of the Geological Society, 158(3):521-534.

Frost B.R., Barnes C.G., Collins W.J., Arculus R.J., Ellis D.J., Frost C.D. 2001. A geochemical classification for granitic rocks. Journal of Petrology, 42:2033-2048.

Frost B.R. \& Frost C.D. 2014. Essentials of igneous and metamorphic petrology. Cambridge: Cambridge University Press, 303 p.

Gava A., Montes A.S.L., Oliveira, E.P. 1984. Granitos alcalinos no sudeste do Piauí. Caracterização geológica, petrográfica e geoquímica. In: Congresso Brasileiro de Geologia, 33. Rio de Janeiro. Anais..., Rio de Janeiro: SBG, 1984, p. 2767-2786.

Gava, A., Nascimento, D.A., Vidal, J.L.B., Ghignone J.I., Oliveira E.P., Santiago Filho A.L., Teixeira W., Stanford W.J.P., Ribeiro A.G., Ribeiro J.H.M.et al., 1983. Geologia. In: DNPM, Projeto RADAMBRASIL. Folha SC-24/25 - Aracaju/Recife. Rio de Janeiro: DNPM, p. 27-376.

Gomes F.E.M. \& Vasconcelos A.M. 1991. Programa de Levantamentos Geológicos Básicos do Brasil. Carta Geológica, carta metalogenética, Escala 1:100.000, Folha SC.24-V-A-II, Paulistana, Estados de Pernambuco e Piauí. Brasília: DNPM/CPRM, 146 p.
Gonswami B. \& Bhattacharyya C. 2014. Petrogenesis of shoshonitic granitoids, eastern India: implications for the late Grenvillian postcollisional magmatism. Geoscience Frontiers, 5:821-843.

Irvine T.N. \& Baragar W.R.A. 1971. A guide to the chemical classification of the common volcanic rocks. Canadian Journal of Earth Sciences, 8:523-548.

Jardim de Sá E.F., Macedo M.H.F., Kawashita K., Peucat J.J., Leterrier J., Fuck R.A. 1996. A Suíte Serra da Esperança: intrusões alcalinas sintectônicas aos nappes brasilianos na Faixa Riacho do Pontal, NE do Brasil. In: Congresso Brasileiro de Geologia, 39. Salvador. Anais..., Salvador, SBG, 1996, v. 6, p. 499-501.

Jardim de Sá E.F., Macedo M.H.F., Torres H.H.F., Kawashita K. 1988. Geochronology of metaplutonics and evolution of supracrustal belts in the Borborema Province, NE Brazil. In: Congresso LatinoAmericano de Geologia. Belém. Anais..., Belém, 1988, v. 7, p. 49-62.

Kosin M.D., Angelim L.A.A., Souza J.D., Guimarães J.T., Teixeira L.R., Martins A.A.M., Bento R.V., Santos R.A., Vasconcelos A.M., Neves J.P., Wanderley A.A., Carvalho L.M., Pereira L.H.M., Gomes I.P. 2004. Folha SC.24-Aracaju. In: Schobbenhaus C., Gonçalves J.H., Santos J.O.S., Abram M.B., Leão Neto R., Matos G.M.M., Vidotti R.M., Ramos M.A.B., Jesus J.D.A. (Eds.). Carta geológica do Brasil ao Milionésimo, Sistema de Informações Geográficas. Programa Geologia do Brasil. Brasília: CPRM, CD-ROM.

Kreysing K., Lenz R., Ribeiro G.F. 1973. Salinização das águas subterrâneas do centro do polígono das secas do nordeste brasileiro. Recife: Sudene, 69 p.

Lara P., Oyhantcabal P, Kelsie D. 2015. Post-collisional, Late Neoproterozoic, high-Barium and Strontium granitic magmatism of adakitic affinity from the Dom Feliciano Belt and its cratonic foreland. In: Hutton Symposium, 8, Florianópolis, Abstract Books.

Liz J.D., Lima E.F., Nardi L.V.S. 2009. Avaliação de fontes magmáticas de séries shoshoníticas pós-colisionais com base na normalização pela Associação Shoshonítica de Lavras do Sul. Revista Brasileira de Geociências, 39(1):55-66

Maniar P.D. \& Piccoli P.M. 1989. Tectonic discriminations of granitoids. Geological Society of America Bulletin, 101:635-643.

Marimon M.P.C. 1990. Petrologia e litogeoquímica da sequência plutono-vulcanosedimentar de Brejo Seco, município de São João do Piauí. MS Dissertation, Universidade Federal da Bahia, Salvador, $102 \mathrm{p}$.

Melo S.C. \& Guimarães M.T. 2011. Caracterização litogeoquímica da Suíte Serra da Aldeia, Folha Barragem (SC.23-X-B-VI), Piauí, Nordeste do Brasil. In: Congresso Brasileiro de Geoquímica, 13, e Simpósio de Geoquímica dos Países do Mercosul, 3, Gramado, p. 939-942.

Middlemost E.A.K. 1985 Magmas and magmatic rocks: an introduction to igneous petrology. London/New York, Longman, $266 \mathrm{p}$.

Moraes J.F.S. 1992. Petrologia das rochas máficas-ultramáficas da sequência vulcanosedimentar de Monte Orebe, PE-PI. MS Dissertation, Universidade Federal da Bahia, Salvador, 98 p.

Nardi L.V.S. \& Bonin B. 1991. Post-orogenic and non-orogenic alkaline granite associations: the Saibro intrusive suite, southern Brazil — a case study. Chemical Geology, 92(1-3):197-211.

Nardi L.V.S. \& Bitencourt M.F. 2007. A-type granites and rhyolites: suggestions for their recognition in postcollisional settings. In: Congresso Brasileiro de Geoquímica, 11, Atibaia. Anais..., São Paulo, SBGq, 1.

Nardi L.V.S. \& Bitencourt M.F. 2009. A-type granitoids in postcollisional settings from southernmost Brazil: their classification and relationship with magmatic series. Canadian Mineralogist, 47:1493-1504 
Nardi L.V.S., Pla Cid J., Bitencourt M.F., Stabel L.Z. 2008. Geochemistry and petrogenesis of post-collisional ultrapotassic syenites and granites from southernmost Brazil: the Piquiri Syenitic Massif. Anais da Academia Brasileira de Ciências, 80:353-372.

Nono G.D.K., Nzenti J.P., Suh C.E., Ganno S. 2010. Geochemistry of ferriferous, high-K calc-alkaline granitoids from the BanefoMvoutsaha Massif (NE Bafoussam), Central Domain of the Pan- African Fold Belt, Cameroon. The Open Geology Journal, $4: 15-28$

Okonkwo C.T. \& Folorunso I.O. 2013. Petrochemistry and geotectonic setting of granitic rocks in Aderan Area, S.W. Nigeria. Journal of Geography and Geology, 5(1):30-44.

Oliveira R.G. 1998. Arcabouço geotectônico da região da Faixa Riacho do Pontal, Nordeste do Brasil: dados aeromagnéticos e gravimétricos. MS Dissertation, Universidade de São Paulo, São Paulo, 157 p.

Oyhantçabal P., Siegesmund S., Wemmer K., Frei R., Layer P. 2007. Post-collisional transition from calc-alkaline to alkaline magmatism during transcurrent deformation in the southernmost Dom Feliciano Belt (Braziliano-Pan-African, Uruguay). Lithos, 98(1):141-159.

Pearce J.A. 1982. Trace element characteristics of lavas from destructive plate margins. In: Thorpe R.S. (Ed.). Andesites. New York, John Wiley, p. 525-548.

Pearce J.A. 1996. Sources and settings of granitic rocks. Episodes, 19(4).

Pearce J.A., Harris N.W., Tindle A.G. 1984. Trace element discrimination diagrams for the tectonic interpretation of granitic rocks. Journal of Petrology, 25:956-983.

Peccerillo A. \& Taylor S.R. 1976. Geochemistry of Eocene calcalkaline volcanic rocks from the Kastamonu area, Northern Turkey. Contributions to Mineralogy and Petrology, 58:63-81.

Plá Cid J., Nardi L.V.S., Conceição H., Bonin B., Jardim de Sá E.F. 2000. The alkaline silica-satured ultrapotassic magmatism of the Riacho do Pontal Fold Belt, NE Brazil. Journal of South American Earth Sciences, 13(7):661-683.

Rollinson H.R. 1993. Using geochemical data: evaluation, presentation, interpretation. New York, Longman, 352 p.

Rollinson H.R. 2014. Using geochemical data: evaluation, presentation, interpretation. United Kingdom, Routledge.
Salgado S.S. 2014. Geologia, contexto geotectônico e potencial metalogenético para depósitos de Ni-Cu- (EGP) do Complexo máficoultramáfico de Brejo Seco, Faixa Riacho do Pontal, sudeste do Piauí. MS Dissertation, Universidade Federal de Minas Gerais, Belo Horizonte, $97 \mathrm{p}$.

Santos C.A. \& Silva Filho M.A. 1990. Programa Levantamentos Geológicos Básicos do Brasil. Riacho do Caboclo, escala 1:100.000. Folha SC.24-V-A-VI. Estados de Pernambuco e Bahia, CPRM, 113 p.

Sial A.N., Vasconcelos P.M., Ferreira V.P., Pessoa R.R., Brasilino R.G., Morais Neto J.M. 2008. Geochronological and mineralogical constraints on depth of emplacement and ascension rates of epidotebearing magmas from northeastern Brazil. Lithos, 105:225-238.

Souza J.D., Fernandes Filho J., Guimarães J.T., Lopes J.N. 1979. Projeto Colomi. Relatório Final. Geologia da Região do Médio São Francisco, texto e mapas. Escala 1:250.000. Salvador, DNPM-CPRM, 389 p.

Sun S.S. \& McDonough W.F. 1989. Chemical and isotopic systematics of oceanic basalts: implications for mantle composition and processes. In: Saunders A.D., Norry M.J. (Eds.). Magmatism in the ocean basins. Geological Society of London, Special Publication, 42:313-345.

Tarney J. \& Jones C.E. 1994. Trace element geochemistry of orogenic igneous rocks and crustal growth models. Journal of the Geological Society, 151(5):855-868.

Thompson R.N. 1982. Magmatism of the British Tertiary volcanic province. Scottish Journal of Geology, 18:50-107.

Trompette R.R. 1994. Geology of western Gondwana (2000-500 Ma) Pan-African-Brasiliano aggregation of South America and Africa. Rotterdam, Balkema, 350 p.

Van Schmus W.R., Brito Neves B.B., Hackspacher P., Babinsk M. 1995. $\mathrm{U} / \mathrm{Pb}$ and $\mathrm{Sm} / \mathrm{Nd}$ geochronologic studies of eastern Borborema Province, northeastern Brazil: initial conclusions. Journal of South American Earth Sciences, 8:267-288

Winter J.D. 2001. An introduction to igneous and metamorphic petrology. Prentice Hall, New Jersey, 697 p.

Zhang Y., Sun M., Yuan C., Xu Y., Long X., Tomurhuu D., He B. 2015. Magma mixing origin for high $\mathrm{Ba}-\mathrm{Sr}$ granitic pluton in the Bayankhongor area, central Mongolia: response to slab roll-back. Journal of Asian Earth Sciences, 113:353-368.

Available at www.sbgeo.org.br 